
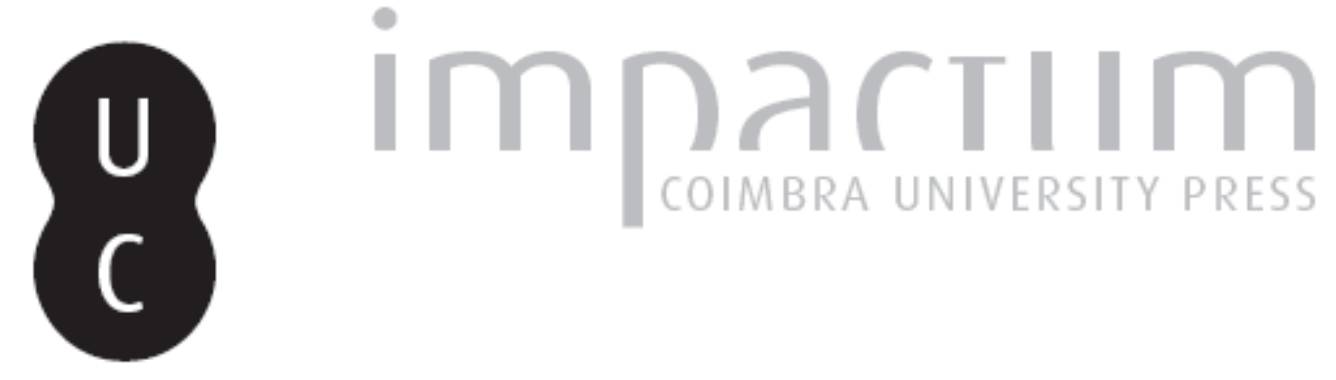

\title{
A paisagem, uma ferramenta de análise de territórios emergentes na interface entre natureza e sociedade: o vale do Guaporé: Jauru/MT-Brasil
}

Autor(es): $\quad$ Passos, Messias Modesto dos

Publicado por: Imprensa da Universidade de Coimbra

URL persistente:

URI:http://hdl.handle.net/10316.2/43407

DOI:

DOI:https://doi.org/10.14195/0871-1623_36_3

Accessed : $\quad$ 26-Apr-2023 14:26:48

A navegação consulta e descarregamento dos títulos inseridos nas Bibliotecas Digitais UC Digitalis, UC Pombalina e UC Impactum, pressupõem a aceitação plena e sem reservas dos Termos e Condições de Uso destas Bibliotecas Digitais, disponíveis em https://digitalis.uc.pt/pt-pt/termos.

Conforme exposto nos referidos Termos e Condições de Uso, o descarregamento de títulos de acesso restrito requer uma licença válida de autorização devendo o utilizador aceder ao(s) documento(s) a partir de um endereço de IP da instituição detentora da supramencionada licença.

Ao utilizador é apenas permitido o descarregamento para uso pessoal, pelo que o emprego do(s) título(s) descarregado(s) para outro fim, designadamente comercial, carece de autorização do respetivo autor ou editor da obra.

Na medida em que todas as obras da UC Digitalis se encontram protegidas pelo Código do Direito de Autor e Direitos Conexos e demais legislação aplicável, toda a cópia, parcial ou total, deste documento, nos casos em que é legalmente admitida, deverá conter ou fazer-se acompanhar por este aviso.

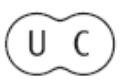




\section{Cadernos de Ceografia}

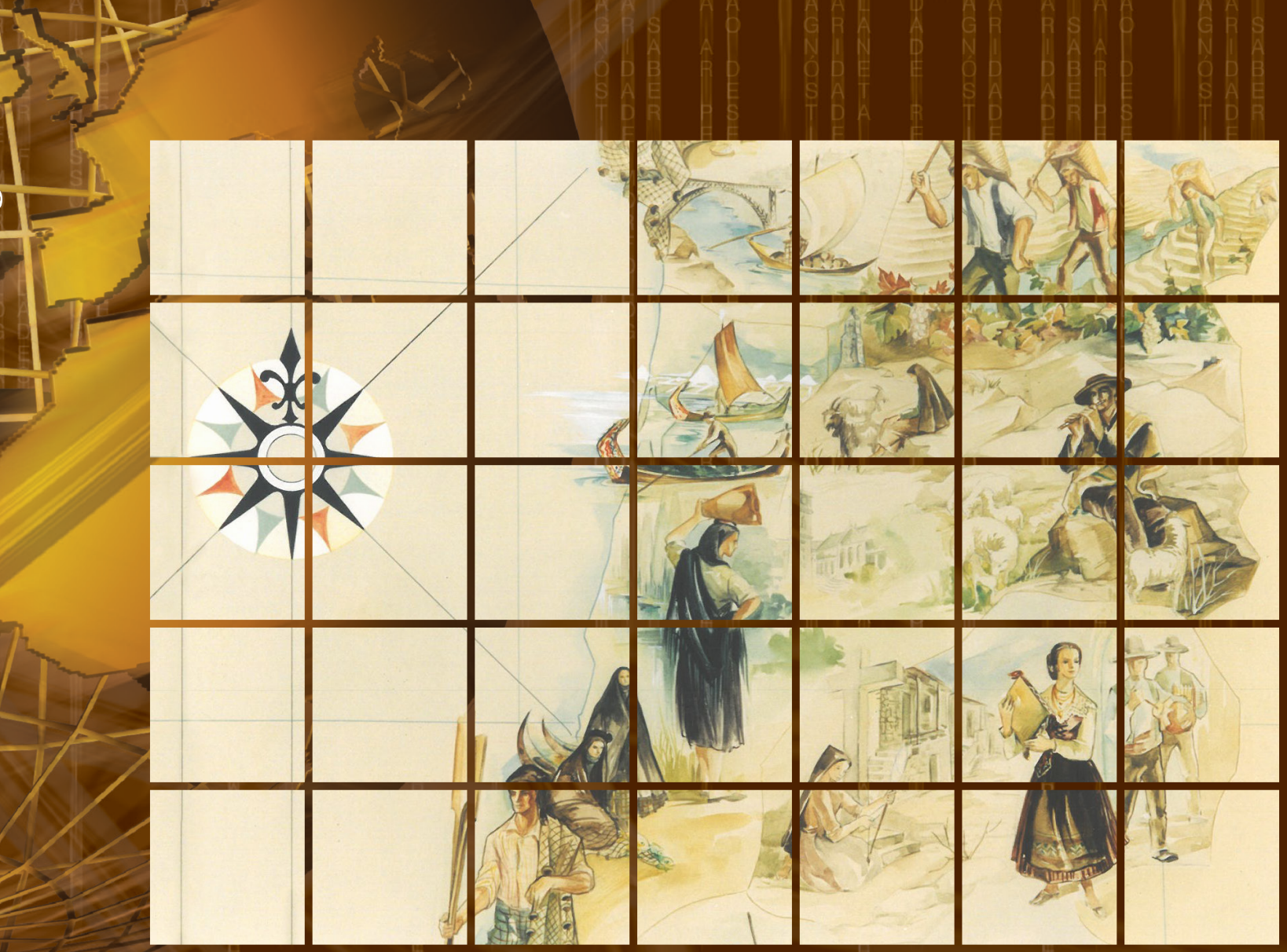

Imprensa da Universidade de Coimbra Faculdade de Letras | Universidade de Coimbra 


\title{
A paisagem, uma ferramenta de análise de territórios emergentes na interface entre natureza e sociedade: o vale do Guaporé - Jauru/MT-Brasil The landscape, a tool for analysing emerging territories at the interface between nature and society: the Guaporé valley - Jauru/MT-Brasill
}

\author{
Messias Modesto dos Passos \\ Programa de Pós-Graduação em Geografia da UNESP - Campus de Presidente Prudente/SP \\ mmpassos86@gmail.com \\ ORCID: 0000-0002-0360-7612
}

\section{Resumo:}

No Brasil, importantes mudanças ambientais e sociais afetam o país. A gestão dos recursos naturais se coloca de maneira crucial ante a pressão antrópica. Após a Rio-92, o país se engajou na promoção de uma gestão sustentável do meio ambiente. A comunidade científica reconhece que as questões de sustentabilidade devem ser abordadas globalmente, integrando a interação das dinâmicas naturais, socioeconômicas e socioculturais. Neste contexto de "pluridisciplinaridade necessária" para abordar as variáveis do desenvolvimento sustentável, nós propomos uma problemática de pesquisa centrada sobre a "paisagem" (Bertrand, 2002) como ferramenta de diálogo entre ciências naturais e ciências sociais em torno de questões socioambientais. Este artigo objetiva mostrar como a paisagem é um indicador dos processos de antropização de territórios emergentes - o vale do Guaporé-Jauru/sudoeste do estado do Mato Grosso-Brasil -, e em que medida ela é uma ferramenta de análise pertinente das dinâmicas espaciais na interface natureza-sociedade.

Palavras-chave: Paisagem; Amazônia; Natureza-sociedade; Desenvolvimento sustentável.

\section{Abstract:}

In Brazil, important environmental and social changes affect the country. The management of natural resources arises crucially before the anthropic pressure. After Rio-92, the country engaged in the promotion of sustainable management of the environment. The scientific community recognizes that sustainability issues should be addressed globally, integrating the interaction of natural dynamics, socio-economic and socio-cultural. In this context of "necessary pluridisciplinarity" to address the variables of sustainable development, we propose a research problem focused on the "landscape" (Bertrand, 2002) as a tool of dialogue between natural sciences and social sciences around environmental issues. This article aims to show how the landscape is an indicator of anthropic processes emerging territories - the valley of Guaporé-Jauru / southwestern state of Mato Grosso, Brazil - and to what extent it is a pertinent analysis tool of spatial dynamics in interface nature-society.

Keywords: Landscape; Amazon; Nature and society; Sustainable development.

\section{Problemática}

Se há um contraste de paisagem, há, também, um contraste político-administrativo. Para conhecer a Geografia Física é preciso conhecer os problemas sociais, econômicos, administrativos...

O Brasil chama atenção pela diversidade e rapidez das mudanças socioeconômicas e ambientais que o afetam. Há regiões em pleno processo de emergência, como a do arco de colonização agrícola na Amazônia - Vale do Guaporé-Jauru -, onde as alterações são muito notáveis. Esta região está na mídia nacional e internacional pelos impactos dos desmatamentos sobre a regressão da biodiversidade. Esta região apresenta meios complexos, onde a geo- diversidade se erode ao contacto de fortes mutações naturais e sociais. Os ecossistemas variados dessa parcela do território brasileiro são confrontados com transformações aceleradas devidas a organização espacial e aos tipos de exploração muito agressivos. No arco da colonização agrícola, 0,5 a 1 \% da floresta amazônica passa do status de ecossistema natural para o de paisagem rural, sem que se observe sistematicamente uma melhora significativa dos indicadores de desenvolvimento humano (IDH).

Na Amazônia a combinação de fatores biofísicos de uma parte, e as múltiplas iniciativas e ações humanas motivadas pelos interesses econômicos de outra parte, conduzem a grandes dificuldades de acompanhamento, em tempo real, do conhecimento científico desses meios, e cuja identificação das 
políticas públicas permite engajar estas regiões na via do desenvolvimento sustentável. É, sem dúvida, nesta via que o Brasil deseja se orientar depois dos acordos assinados durante a Conferencia Internacional das Nações Unidas sobre Meio Ambiente e Desenvolvimento Humano - a Eco-92. A noção de sustentabilidade, que introduziu a reflexão e a ação em matéria de desenvolvimento, se apresenta em definitivo muito clara: a referência à lógica de progresso das sociedades humanas, coloca a ênfase sobre a necessária articulação entre a viabilidade econômica das formas tomadas por este desenvolvimento, sua capacidade de não colocar em perigo os recursos ambientais sobre os quais ele se funda, e o caráter equitativamente benéfico de seus efeitos sobre os diferentes grupos sociais (Conferência Mundial sobre o desenvolvimento sustentável, 2002). É, portanto, neste "conceito" que as questões de sustentabilidade devem ser entendidas, ou seja, integrando as questões que correspondem aos meios naturais e às dinâmicas sociais. Lembramos que, não se trata de identificar e de proteger os meios frágeis de um lado e de outro de "sacrificar" regiões em nome de um desenvolvimento econômico e social, mas, sobretudo, de conservar os meios nos quais as sociedades possam se desenvolver em plena coerência.

Neste contexto, nós optamos em desenvolver a nossa problemática de pesquisa em torno da noção de "paisagem" - em primeiro lugar pelo caráter aglutinador que the confere. Bertrand (2002) edificou as bases conceituais da paisagem como meio de fazer dialogar as ciências naturais e as ciências sociais em torno de questões socioambientais. Em seguida Deffontaines (1998) deu um caráter concreto e operatório à abordagem paisagística para que ela traduza e revele os modos de funcionamento e de organização dos espaços, "a paisagem sendo o lugar onde se inscrevem indicadores visuais práticos num meio dado". Assim, a entrada pela paisagem foi retida desde que o interesse em conjugar uma abordagem naturalista, indicadora das dinâmicas biofísicas, à uma abordagem territorial sobre a apreensão pela sociedade dos recursos naturais cuja a gestão depende, notadamente, da escolha e das orientações em relação com as dinâmicas socioeconômicas dos territórios considerados. A paisagem é uma polissemia, ou seja, é o resultado material de um conjunto de interações entre processos físicos, processos ecológicos, processos sociais e processos culturais. $\mathrm{Na}$ verdade, ela é considerada como o "reflexo das relações entre o homem e seu meio ambiente" e aparece assim indissociável do conjunto das dinâmicas territoriais (Béringuier et al. 1999).

\section{A paisagem na Geografia}

“A paisagem é o reflexo e a marca impressa da sociedade dos homens na natureza. Ela faz parte de nós mesmos. Como um espelho, ela nos reflete. Ao mesmo tempo, ferramenta e cenário. Como nós e conosco, ela evolui, móvel e frágil. Nem estática, nem condenada. Precisamos fazê-la viver, pois nenhum homem, nenhuma sociedade, pode viver sem território, sem identidade, sem paisagem."

(Bertrand, 2007).

Pintura, literatura, arte dos jardins foram, por essência, elitistas e, à exceção dos jardins japoneses, não se vulgarizaram antes do fim do século XIX e início do século $X X$. A ideia de paisagem, mais ou menos bem abordada segundo os tempos, os lugares e as disciplinas, ficou por muito tempo um negócio de iniciados.

A partir do século XIX, o termo paisagem é profundamente utilizado em Geografia e, em geral, se concebe como o conjunto de "formas" que caracterizam um setor determinado da superfície terrestre. A partir desta concepção que considera puramente as formas, o que se distingue é a heterogeneidade da homogeneidade, de modo que se podem analisar os elementos em função de sua forma e magnitude e, assim, obter uma classificação de paisagens: morfológicas, vegetais, agrárias etc. Esse conceito de paisagem foi introduzido em Geografia por A. HOMMEYEREM mediante a forma alemã Landschaft, entendendo exatamente por este termo, o conjunto de elementos observáveis desde um ponto alto.

As línguas germânicas apresentam um claro paralelismo através da palavra originária land, com um sentido praticamente igual e da qual derivam landschaft (alemão), landscape (inglês), landschap (holandês) etc. Esse significado de espaço territorial, mais ou menos definido, remonta ao momento da aparição das línguas vernáculas e podemos dizer que esse sentido original, com certas correções, é válido ainda hoje.

A possibilidade de deslocamentos mais rápidos, as epopeias coloniais, a aparição e a difusão da fotografia, o papel da imprensa, o acesso aos romances de aventuras ou regionalistas, a tomada de consciência das agressões das quais as paisagens são vítimas etc., levam à tomada de consciência coletiva da noção comum de paisagem.

\section{As correntes paisagísticas}

A Geografia sempre utilizou a paisagem como uma ferramenta de observação e de hierarquização 
dos fenômenos espaciais, sem que, aliás, verdadeiros consensos metodológicos acontecessem ou fossem impostos sobre níveis pertinentes de análise.

Inicialmente lembremos que há três diferentes correntes de estudo da paisagem:

- uma corrente naturalista

- uma corrente sensível

- uma corrente mais flexível

No entanto, a paisagem, sobretudo considerada no seu aspecto dinâmico de "PROCESSOS PAISAGÍ́STICOS" deve ser estudada como um "POLISISTEMA" formado pela combinação dos sistemas natural, social, econômico, cultural etc.

Para abordar a paisagem adotamos três entradas: materialidade, sensibilidade e representação. Esse posicionamento, conhecido como Tripé Paisagístico (Rennó, 2009) deixa, de acordo com os questionamentos iniciais, com a realidade da região de estudo e com os objetivos, a liberdade de privilegiar mais ou menos cada uma das entradas. Porém, é na sua utilização completa que ela atinge de maneira mais eficaz seus objetivos.

A paisagem se presta, entre outras finalidades, para enraizar o meio ambiente no território dos homens e na longa história das sociedades (enfim, são as sucessivas sociedades que constroem as sucessivas paisagens como lugar para morar, trabalhar e sonhar...).

Há uma corrente, da qual participa Georges Bertrand - a Escola de Toulouse, para a qual a SENSIBILIDADE é atribuída ao sentido de identidade (ressourcement), ou seja, carregada de subjetividade, de imaterialidade... e de poesia. A paisagem está na frente e atrás dos olhos. Para esta corrente, a paisagem está mais "atrás dos olhos".

Segundo esta corrente - "a cada um a sua paisagem" -, não se pode definir a paisagem, mas dizer o que ela representa: identidade cultural (por exemplo: agrestino). É uma referência patrimonial (por exemplo: o Pantanal)... Dentro desse patrimônio há coisas construídas (lugares: morar/trabalhar/sonhar)... Isto é, há uma extensão do meio ambiente...

Uma paisagem nasce, toda vez que um olhar cruza um território... Ou seja, a paisagem nasce da interação de dois elementos: (a) o objeto - um espaço geográfico qualquer -; (b) o sujeito - o observador: é o homem com sua sensibilidade, seus projetos. O mais importante é o que existe entre os dois. Paisagem é um processo! Um modo de representação sociocultural de um espaço.

Atravessamos hoje em dia uma revolução cultural: não apenas científica, mas de todo conjunto. Temos que superar os métodos científicos clássicos para desenvolver uma problemática cultural, científica, social: de complexidade e de diversidade.

Uma nova maneira de ver o mundo das relações humanas com o planeta. Passando da Natureza para a Sociedade. Esse mundo não é somente da Natureza.

O conceito de paisagem-território. A paisagem constitui uma dimensão imprescindível do território... A paisagem produz mais discurso que métodos! Falta uma ferramenta de trabalho teórico-metodológico. A Paisagem Território se define como um fato geográfico territorializado/materializado. Diferente das paisagens dos pintores, dos poetas. Vivemos a Paisagem Território todos os dias. Constitui um sistema territorial de complexidade-diversidade, seja material ou natural. É preciso não deixar a paisagem isolada e, sim, dentro do meio ambiente (geográfico).

É, portanto, a partir de paisagens indicadoras (ou do Sistema Paisagem Território) que nós vamos abordar as dinâmicas paisagísticas do Vale do Guaporé-Jauru/MT.

\section{A paisagem indicadora}

A confrontação dos procedimentos metodológicos com parâmetros "consagrados" por outros grupos de pesquisas ${ }^{1}$ tem duas finalidades: uma é permitir afinar e ajustar o guia metodológico proposto, a fim de torná-lo operacional nos diversos contextos territoriais; a outra é testar/avaliar a paisagem como uma entrada e uma ferramenta pertinente para responder às problemáticas de desenvolvimento sustentável dos territórios.

Em relação à finalidade da paisagem indicadora, podemos apontar três objetivos, que correspondem a diferentes etapas metodológicas.

1 - Identificação de paisagens-indicadoras para um melhor conhecimento territorial na interface natureza-sociedade.

Trata-se de mostrar como a entrada pelas paisagens pode servir para analisar o contínuo espacial segundo um ponto de vista comum, que atenda tanto às ciências da natureza como às ciências sociais e, por consequência, permita construir uma tipologia paisagística que possa servir de linguagem de referência entre as diferentes disciplinas associadas (geografia, pedologia, botânica, teledetecção,...). Esta categorização espacial apresenta o interesse de centrar as análises em torno dos mesmos objetos de observação, de facilitar os cruzamentos e comple-

\footnotetext{
Université de Toulouse Le Mirail; Université de Rennes 2, Université d'Avignon - França.
} 
mentos de informações e de determinar paisagens indicadoras das dinâmicas espaciais. Tudo isso para melhorar os conhecimentos sobre os territórios nas trajetórias da evolução contrastada em função das variáveis socioambientais que tem localmente o desenvolvimento sustentável.

2 - A espacialização das informações para mise en place de "observatórios"2 das dinâmicas paisagísticas.

3 - A detecção de paisagens indicadoras sobre as imagens de satélite tem por objetivo produzir cartas que ofereçam uma visão global e homogênea tanto no tempo como no espaço destes territórios em constante evolução. A ideia é posicionar os "observatórios" para acompanhar os meios agrícolas ou outros e seus contextos ambientais na escala regional das paisagens. Este nível está relacionado com as unidades de gestão territorial às quais se aplicam as políticas públicas e os projetos de desenvolvimento.

A paisagem pode ser um indicador pertinente das dinâmicas espaciais na interface das interações do social e do natural, notadamente onde os terrenos de estudo são de difícil apreensão, em razão da rapidez das mudanças, da carência de dados confiáveis e dos incontornáveis problemas logísticos de coleta de informações locais, devidos ao isolamento e à imensidão desses territórios.

A paisagem-indicadora torna-se então paisagem-integradora, pois ela permite o cruzamento de diferentes informações orientadas segundo uma problemática específica própria a cada dinâmica regional. Este primeiro passo em direção ao melhoramento dos conhecimentos dos meios e das sociedades que os habitam constitui um dos suportes das proposições para a ajuda da decisão em matéria de políticas de desenvolvimento sustentável.

\section{A ocupação da Amazônia matogrossense}

O Centro-Oeste brasileiro é considerado, pelos poderes públicos, como uma região solução para a maioria dos problemas do Brasil. O território pouco povoado, a "disponibilidade" de terras e a possibilidade de se avançar sempre para o Oeste estimularam o avanço da fronteira agrícola que representa um componente ideológico fundamental do consenso social, largamente manipulado pelos governantes.

Os “observatórios" serão, na verdade, áreas georeferenciadas - em meios rurais - para efeito de acompanhamento mais sistemático de suas dinâmicas socioambientais, a partir de imagens de satélite e de observações in locus.
Essa área, devido à sua extensão e à sua situação, às vezes central e fronteiriça, constitui um jogo geopolítico. A fundação de Brasília, em 1960 e a criação de grandes eixos rodoviários ligando Belém a Brasília (Norte-Sul), Cuiabá a Porto Velho e a Santarém (Sul-Norte-Oeste e Sul-Norte) no quadro do Programa de Integração Nacional deveriam impulsionar a ocupação demográfica e o desenvolvimento econômico espontâneo.

Entre 1970 e 1974, o Instituto Nacional de Colonização e Reforma Agrária (INCRA) priorizou o assentamento de colonos pobres nos Estados de Rondônia e Mato Grosso, conforme proposta do projeto Polonoroeste, atendendo a três objetivos básicos: (1) objetivo econômico, ou seja, promover a agricultura, como meta de aumentar a produção de alimentos para abastecer o mercado interno e para a exportação; (2) objetivo demográfico, isto é, frear o êxodo rural e reorientar, para a Amazônia, o fluxo que se dirige para as grandes metrópoles do Sudeste; (3) objetivo social, diminuir as tensões sociais provocadas pelo latifúndio no Nordeste e pelo minifúndio no Sul do País.

O segundo projeto concerne aos cerrados, cujos solos eram avaliados como pobres e impróprios para a agricultura até 1970. A partir de fortes investimentos, graças aos progressos da agricultura e ao desenvolvimento das comunicações, os cerrados atraem os "sulistas" para os Chapadões do Planalto Central, tendo a soja como carro-chefe de uma agroindústria exportadora. Nesse caso, priorizam-se os agricultores provenientes da região Sul, mais aptos e capazes para desenvolverem uma agricultura moderna e competitiva voltada, essencialmente, para os mercados internacionais. Nesse contexto, se dá um processo acelerado de urbanização da fronteira agrícola.

Até o início da década de 1970, o povoamento estava concentrado em Cuiabá e arredores, ou seja, no chamado "Mato Grosso Velho". A partir da década de 1970, surgiram 85 novos municípios, a maioria fruto da colonização privada. Isto significa que até o início de 1970 existiam apenas 34 municípios. Terminada a década de 80 , o número de municípios salta para 95, chegando a 126 no final do milênio.

O surgimento de novos municípios e o aumento populacional se deram à custa de uma grande transformação da paisagem rural e urbana. A derivação antropogênica da paisagem atingiu um alto grau de lesionamento, deixando sinais claros de despreparo dos seus agentes. As mudanças regionais e a acelerada urbanização regional estiveram diretamente relacionadas às transformações políticas, econô- 
micas e sociais no âmbito da incorporação das frentes pioneiras da região amazônica ao espaço e à economia nacional. A partir de 1970, diversos fatores influenciaram esta dinâmica na região. Vários programas especiais e medidas em âmbito federal (PIN, Proterra, Polamazonia, Polocentro etc.) favoreceram um acelerado processo de ocupação "racional" das regiões de cerrado e, sobretudo, de floresta amazônica.

Ribeiro (2002) apresenta uma síntese muito objetiva da motivação e estratégias de ocupação da Amazônia Mato-grossense: "Na década de 1970, o governo brasileiro tornou projeto de estratégia militar a ocupação territorial da Amazônia. De um lado, temia a expansão do socialismo que rondava as fronteiras com países vizinhos. De outro, precisava solucionar conflitos fundiários que se avolumavam no sul do País, em especial no Rio Grande do Sul, com os descendentes de antigos imigrantes europeus do fim do século 19 e começo do século 20. Excedentes dos minifúndios doados pelo governo aos imigrantes, e sucessivamente subdivididos até a insubsistência familiar, os descendentes ocupavam terras públicas e reservas indígenas, causando constrangimentos ao regime militar governante. Somou-se, ainda, o fato de que, em 1974 e 1975, as geadas destruíram os cafezais do norte do Paraná, relevante fonte de riqueza agrícola brasileira. Milhares de agricultores ficaram desempregados e sem horizonte no futuro de curto prazo."

Os estrategistas do Governo, que produziram a doutrina-mestra do regime militar baseada em "Segurança e Desenvolvimento", criaram mais um slogan para dar sentido à ocupação da Amazônia: “Integrar para não Entregar”.

Elegeram Cuiabá como ponto de partida para a epopeia de ocupar a vastidão amazônica nos anos seguintes, a partir de 1973.

Uma série de medidas estratégicas precisaria ser tomada para dar sustentação às intensas migrações previstas para a Amazônia de Mato Grosso, visando principalmente a solucionar os problemas fundiários do Rio Grande do Sul e do Paraná. Com programas especiais de desenvolvimento, o governo federal providenciou a pavimentação das rodovias BR-163, desde Campo Grande, e BR-364, desde Goiás, até Cuiabá. Acabava o longo ciclo do isolamento geográfico histórico de Cuiabá.

Criou-se a Universidade Federal de Mato Grosso no mesmo período, para dar sustentação à ocupação. E também se providenciou a extensão do primeiro linhão de energia elétrica desde Cachoeira Dourada, em Goiás, até Cuiabá.
Programas especiais, como de Cerrados, o Polocentro, que financiou a ocupação inédita de um milhão de hectares de cerrados à agropecuária, no Norte de Mato Grosso, vieram dar sustentação ao povoamento amazônico.

0 gado saiu do Pantanal, onde historicamente viveu, e ganhou as terras altas numa pecuária sobre pastagens formadas, e sob condições mais competitivas.

A pequena produção mato-grossense de subsistência sofreu os primeiros impactos dos colonos gaúchos e paranaenses oriundos das áreas de conflitos fundiários, ou atingidos pelas geadas.

Mudou o perfil de Cuiabá, e do norte de Mato Grosso.

Cuiabá transformou-se no "Portal da Amazônia". Surgiram projetos fundiários de colonização privados como os de Nova Xavantina, Canarana e Água Boa, no Vale do Araguaia, e no norte: os de Sinop, Alta Floresta, Colíder, ao lado de muitos outros. Juína surgiu como um projeto público social de sucesso no noroeste, destinado aos colonos pobres.

Mato Grosso mudava o seu perfil contemplativo histórico, deixando para trás o monopólio da atividade garimpeira como o pilar mais forte de sustentação da sua economia.

Durante mais de 4 séculos o Mato Grosso ficou, por causa da sua posição geográfica e das dificuldades de acesso, mais ou menos isolado dos grandes ciclos que marcaram a vida econômica do Brasil.

Os rios eram, então, o único meio utilizado por alguns aventureiros ou exploradores para penetrar este mundo distante.

É bem representado este tempo, em que o ouro era abundante no sítio da cidade e atraía uma importante população de garimpeiros a ponto de fazer de Cuiabá a terceira cidade do País. Era o século 19.

$\mathrm{Na}$ verdade, a pesquisa de ouro e de diamantes se deslocou de Cuiabá para outras regiões de Mato Grosso. Diamantino, por exemplo, tira seu nome da explotação de diamante. Sobretudo, muitos garimpeiros vieram do estado da Bahia desde os anos 1920, a partir do declino das minas de Lençóis, na Chapada Diamantino e, então, se instalaram ao longo dos rios e fundos de vales do Centro-Oeste. Estes são em geral clãs familiares, como no garimpo de ouro e diamantes em Poxoréo, por exemplo.

A abertura das estradas rompe em parte o isolamento do Centro-Oeste e, com a chegada dos militares ao poder, em 1964, o Mato Grosso, como a Amazônia, é progressivamente integrado à economia nacional e mundial. Desde 1976, a BR-163 liga Cuiabá a Santarém; em 1984, a nova estrada Cuiabá - 


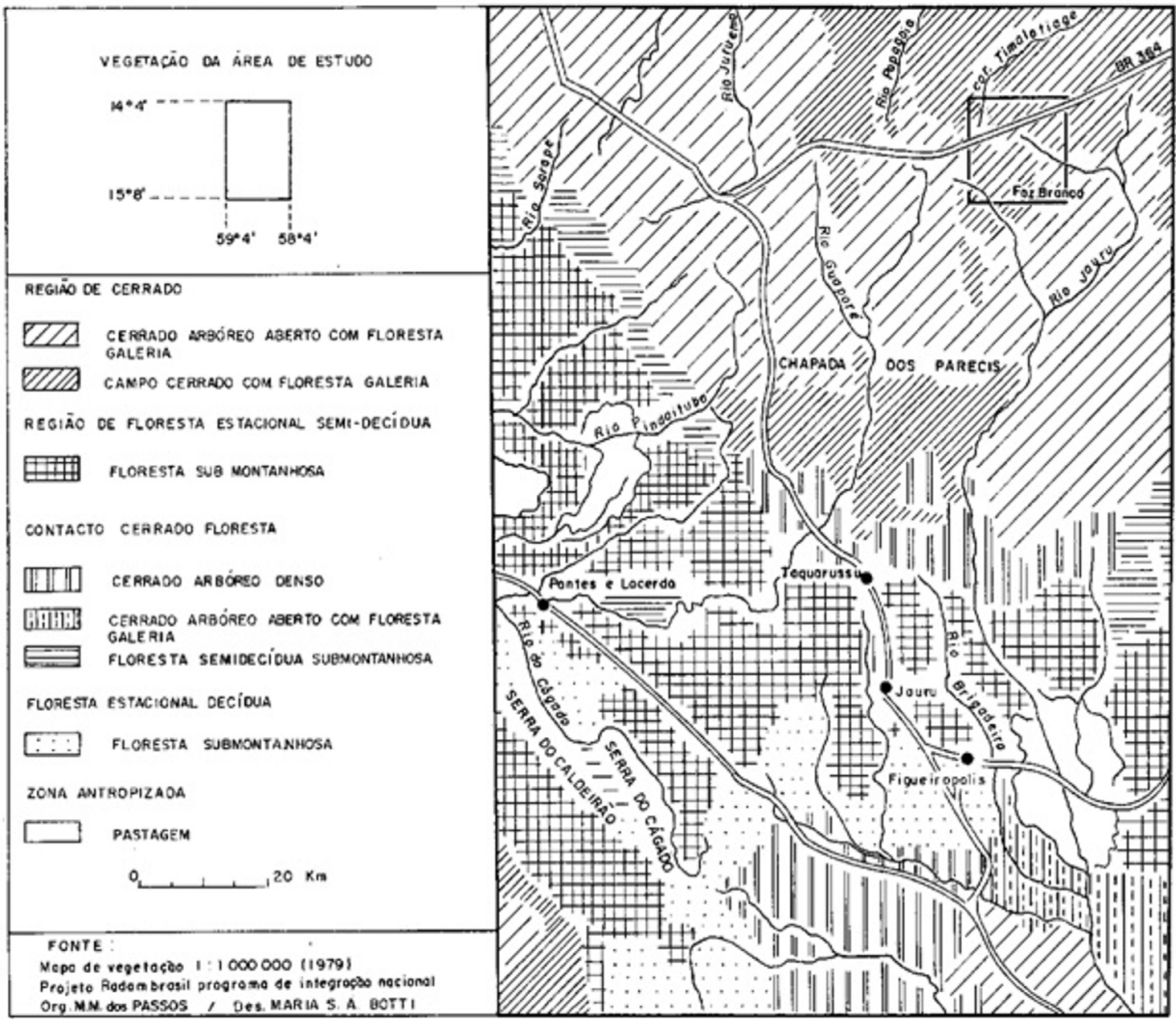

Figura 1

Uso da Terra no Sudoeste do Mato Grosso - Mapa produzido a partir das imagens LANDSAST de 15/10/1992.

Fonte: Extraído de Passos, 1998, p. 110.

Porto Velho é asfaltada. E o Mato Grosso como o sul da Amazônia oscila progressivamente na área de influência do Sul e do Sudeste do Brasil.

Nos anos 1970, diferentes programas de investimentos e de modernização agrícola são elaborados no seio da Superintendência de Desenvolvimento do Centro Oeste/SUDECO e da Superintendência de Desenvolvimento da Amazônia/SUDAM. Sucedem-se então uma série de planos entre os quais o PROCEDER, para a agricultura nos cerrados, o PROTERRA, para a formação de pastagens, o PROBOR para a borracha.

\section{O vale do Guaporé-Jauru}

A partir das imagens Landsat TM $228070 \mathrm{C}$ e 228071A elaboramos a Figura 1, no sentido de mapear o uso da terra no Sudoeste do Mato Grosso - Vale do Guaporé-Jauru.

Ao norte da área, mais precisamente ao longo do eixo da BR-364, na Chapada dos Parecis, observa-se o avanço de agricultura altamente tecnificada em ambientes de cerrado. A melhor ilustração dessa modernização está na Fazenda Itamaraty Norte, cujo complexo agroindustrial é dos mais modernos do Brasil (Figura 2).

Apesar da baixa fertilidade das Areias Quartzosas, a área de cerrado da Chapada dos Parecis mostra-se, ecologicamente, apta para produzir culturas anuais com uso sustentado de corretivos e fertilizantes em um sistema de rotação de lavouras durante ciclos mais ou menos prolongados, segundo o grau de tolerância dos solos. Diante da "marcha do capital para o campo", pode-se prever que o processo de eliminação das atuais áreas de cerrado 


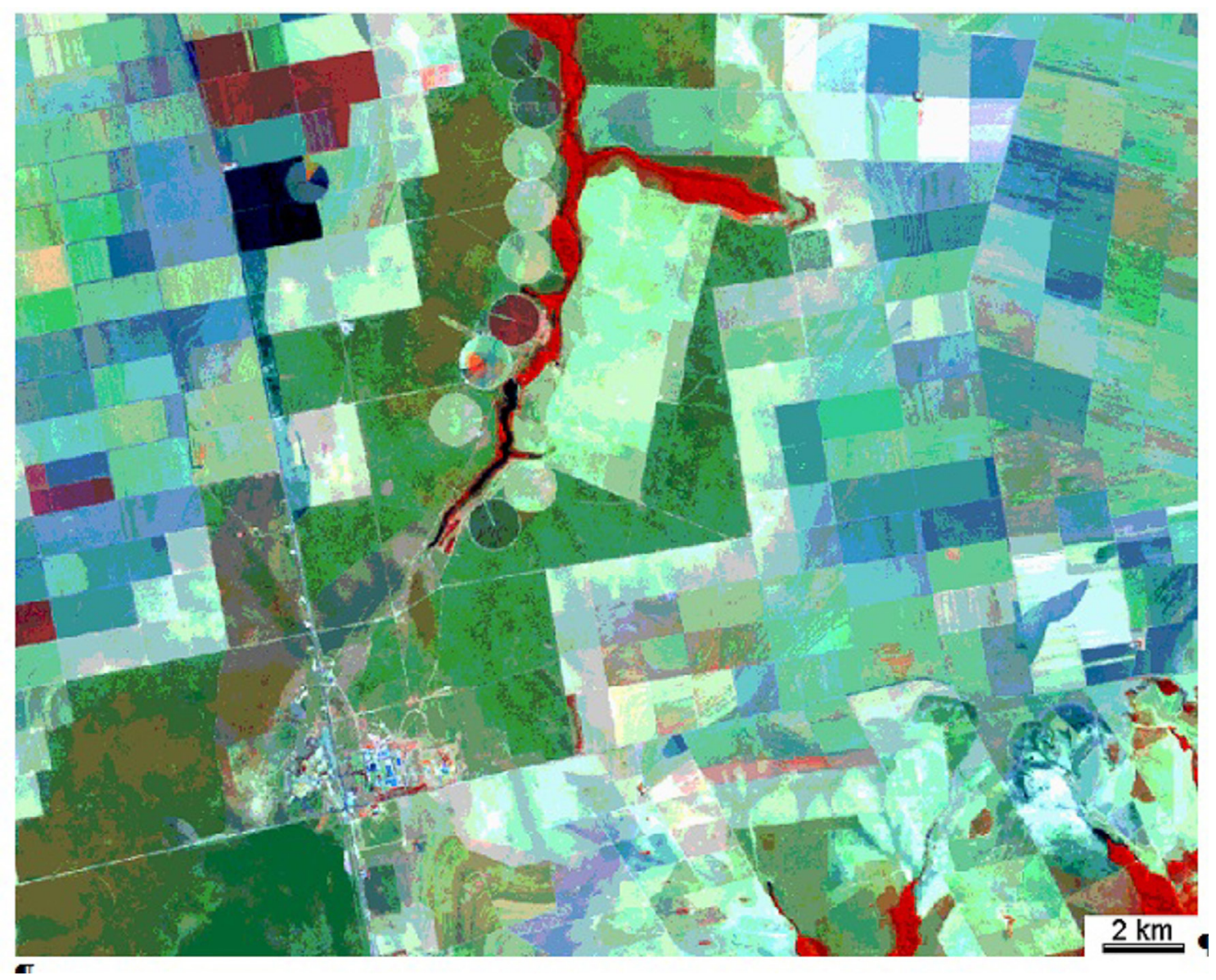

Figura 2

Fazenda Itamaraty Norte/Chapada dos Parecis/Noroeste do estado do Mato Grosso: observar o rio do Sangue (vermelho) ao longo do qual estão instalados os pivôs de irrigação. As parcelas geométricas, em tonalidades distintas, se referem ao cultivo de soja..., em diferentes estágios - Imagem produzida a partir da CC 4-5-3, efetuada na imagem LANDSAT TM 228.070C, datada de 4/7/99.

Fonte: Passos, 08/2010.

para introdução da soja ou mesmo para a formação de pastagens em áreas de topografia mais movimentada, que vem ocorrendo na área, a partir de 1970, seja mantido, em detrimento da proteção das cabeceiras dos rios Guaporé e Jauru e, pior, em total desrespeito às Reservas Indígenas aí existentes.

Descendo a Chapada dos Parecis, em direção ao sul, chega-se à área de floresta do Planalto do Alto Jauru, Vale do Guaporé. É nessa porção do território que o desmatamento foi mais intenso; no início, para o plantio de culturas anuais e, após, para a formação das fazendas. Com exceção da Fazenda Triângulo, onde se observa a área de heveacultura (sudoeste da área), há predomínio das áreas de pastagens com destaque de algumas manchas significativas de mata que aparecem "ilhadas" pelo capim colonião ou pela brachiária em claro processo de coalescência.(Figuras 3 e 4).
As pequenas áreas de solo nu são, na verdade, pastagens em processo de renovação, ou seja, o capim colonião introduzido no início (1972) já não apresenta o mesmo vigor e está sendo gradeado para ceder o espaço à brachiaria, mais tolerante às pragas, ao período seco e à perda de fertilidade do solo.

Nos Planaltos Residuais do Alto Guaporé (Serra Azul, Serra do Cágado e Serra do Caldeirão), observam-se uma mescla entre áreas florestadas, vegetação serrana, cerrado e solo nu. Na verdade, os fatores ambientais (topografia, declividade, fertilidade do solo, umidade edáfica etc.) impõem limites à derivação antropogênica da paisagem.

A "geometria" espacial do sul da região se mostra menos definida e retalhada, exibindo um quadro cujos limites das áreas de culturas (Gleba Mirassolzinho, entre o rio Guaporé e o córrego Irara - Figura 4) com as pastagens artificiais, os desmata- 


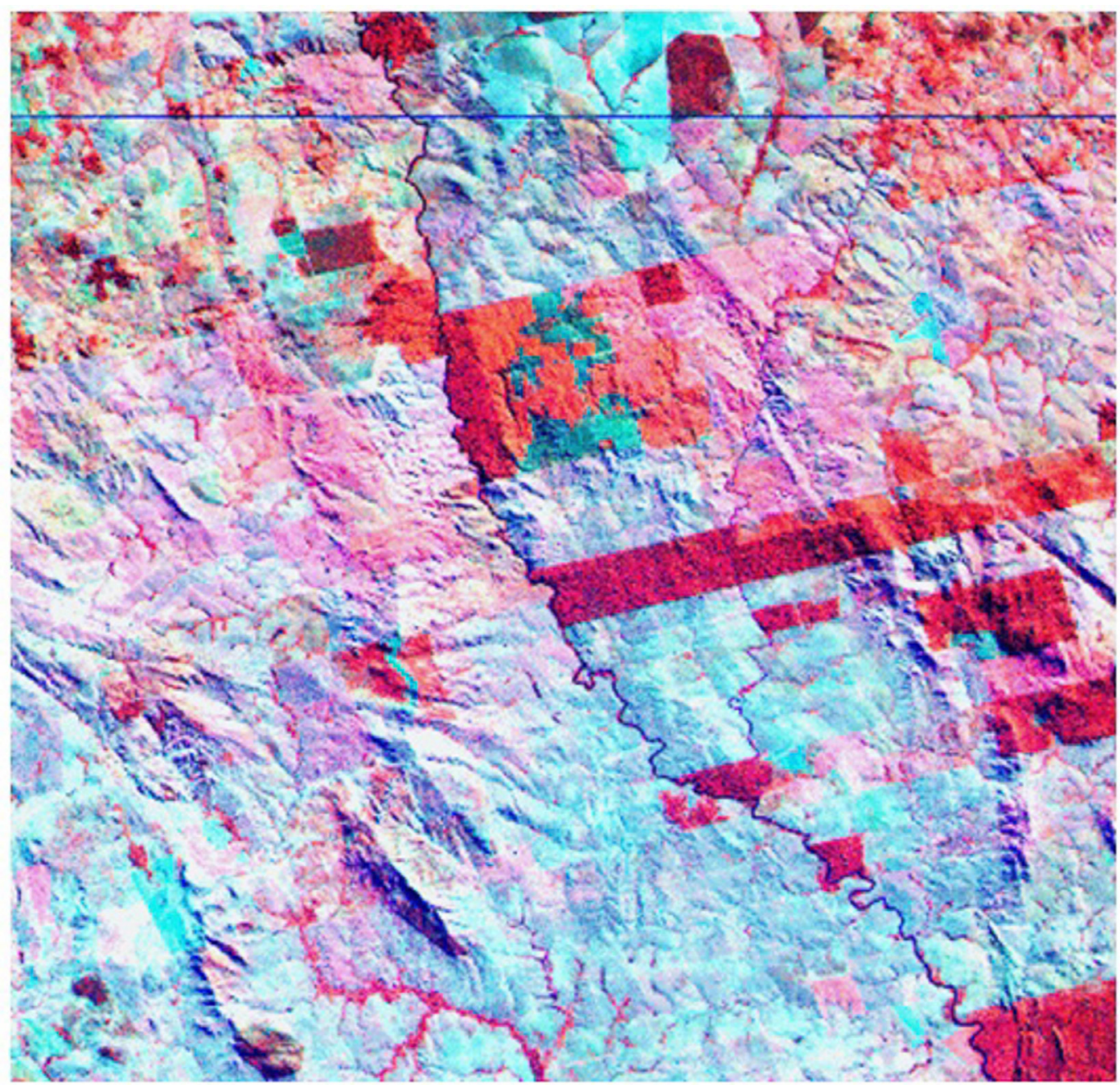

Figura 3

Área de pecuária do Vale do Guaporé-Jauru/Sudoeste do Mato Grosso. Imagem Landsat TM - 228.070, datada de 15/10/1994 -: (a) observar o curso do rio Jauru; (b) as áreas de pastagens (azul) e, notadamente os resíduos de florestas, algumas delas em tom alaranjado (indicador de desmatamento recente).

Fonte: Passos, 08/2010.

mentos recentes e as manchas de florestas relativamente "preservadas" são de difícil demarcação.

A prognose é de que toda essa porção do território, a exemplo da sua faixa central, seja predominantemente ocupada pelas pastagens artificiais.

\section{Evolução do uso da terra no Vale do Guaporé-Jauru:} as paisagens indicadoras

Considerando as imagens do satélite Landsat do município de Jauru/MT - que se presta como referência da evolução do solo no Vale do Guaporé-Jauru -, constatamos que as áreas de floresta estão concentradas, sobretudo no topo das chapadas e no quadrante sul da imagem em uma grande área de interflúvio; no centro da imagem a atividade das pastagens é intensa, essa distribuição é favorecida principalmente pela própria dinâmica da presença de vegetação no cerrado. A presença de cerrados e cerradões está predominantemente nos interflúvios e vertentes suaves dos diferentes tipos de planaltos regionais. Já as áreas de campos limpos e campestres, foram substituídos pela pastagem sem a necessidade primária de grandes derrubadas de matas. A substituição de áreas de matas por pastagens também é perceptível ao comparar as imagens de 1990, 2005 e 2010 (Figuras 8, 9 e 10), principalmente entre 1990 e 2010 onde a quantidade passa de $29 \%$ para $19 \%$ do total do município, período de depressão da econo- 
mia brasileira com queda na agricultura e fortalecimento da pecuária de exportação que se reflete em Jauru-MT. Outra grande modificação é o aumento significativo das áreas de pastagem que passam de $13 \%$ para o ano de 1990, para $17 \%$ no ano de 2005 e 20\% em 2010 juntamente com as áreas de campo/ pastagem, chamadas assim áreas onde a floresta ou as áreas de campos limpos ou sujos, foram substituídas pela pastagem, que passa de $36 \%$ em 1990, para $41 \%$ em 2005 e se mantém no mesmo percentual (41\%) em 2010, que evidenciam a intensa incorporação da atividade pecuária pela sociedade.

As áreas de solo nu são evidenciadas principalmente pelas áreas de topos de morros, sua diminuição de 3\% em 1990 para 2\% em 2005 e 1\% em 2010 se deve principalmente pela recomposição da vegetação de floresta. Esse indicador está intimamente ligado a um segundo indicador que é o aumento das áreas de campo/cerrado que passam de $19 \%$ em 1990 , para 21\% em 2005 e $24 \%$ em 2010, justificado pelo ativo processo natural de recolonização da mata tropical subcaducifólia.

Nessa unidade assentada em território da Bacia do Prata, ainda estão presentes na paisagem as casas de adobe, com batentes de madeira de bitola larga e uma ou outra espécie frutífera, testemunhos da divisão da área em pequenas e médias propriedades (50 a 200 ha), que a partir de meados dos anos 1980, passaram a ser compradas pelos fazendeiros e, assim, agregadas às grandes fazendas de gado do vale do Jauru-Guaporé (Figura 4).

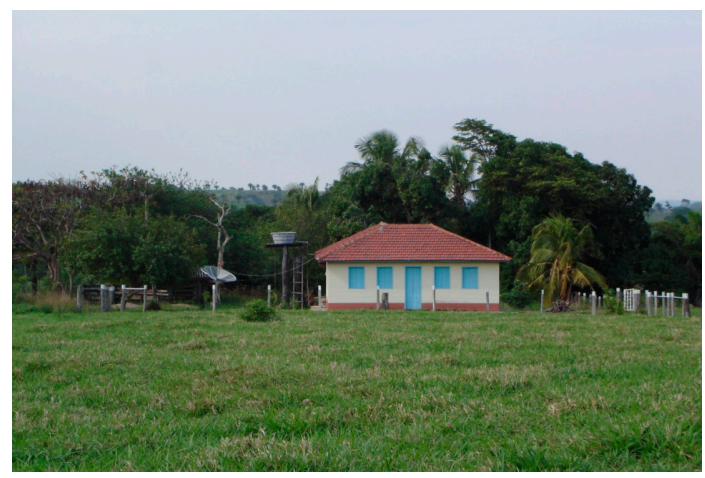

Figura 4

Casa típica da área rural do estado de Minas Gerais, cuja localização foi georrefenciada: $15^{\circ} 12^{\prime} 46.9^{\prime \prime} \mathrm{S}$ - 58 $53^{\prime} 29.8^{\prime \prime} \mathrm{W}$ - Altitude: $476 \mathrm{~m}$ - e que se presta como "paisagem indicadora" da presença de colonos do estado de Minas Gerais que chegaram ao vale do Guaporé-Jauru, no final da década de 1950.

Fonte: Passos, 07/04/2016.

As fazendas de gado do vale do Guaporé-Jauru enfrentam, atualmente, alguns problemas: (a) as invasões organizadas pelo Movimento dos Sem Terra/

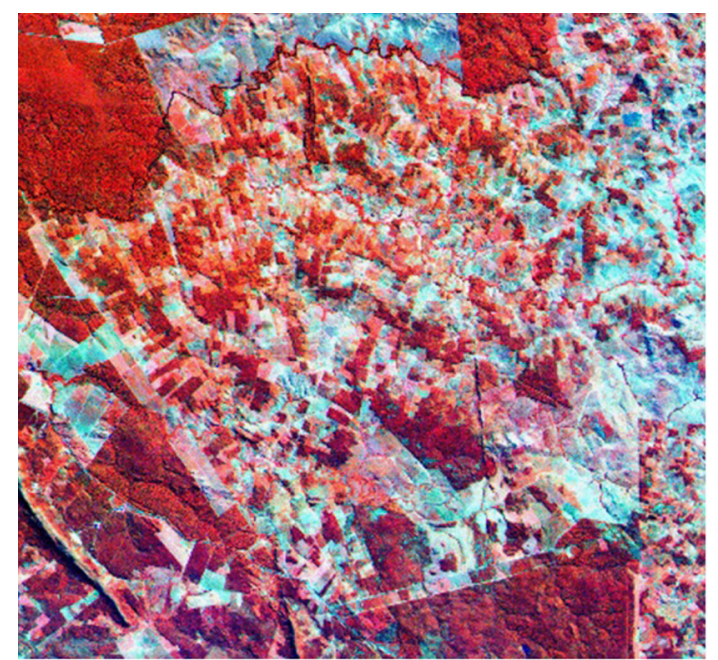

Figura 5

Área de ocupação espontânea. Imagem da "Gleba Mirassolzinho", produzida a partir do tratamento digital (CC 4-5-3) da imagem LANDSAT TM 228.070C, datada de 15/10/1994, no sentido de visualizar o "uso da terra". A ocupação espontânea não define uma geometria precisa das parcelas ocupadas: os tons azulados representam parcelas de uso agrícola. Os tons vermelhos: floresta e os tons alaranjados: desmatamentos recentes. Embora a área tenha sido ocupada por agricultores sem-terra, observa-se o avanço de pastagens e o agrupamento dos lotes. Ainda assim, a produção de gêneros de primeira necessidade (arroz, feijão, mandioca, milho, frutos, legumes etc.) abastece os mercados consumidores de Jauru e de Pontes e Lacerda. Fonte: Passos, 08/2010.

MST; (b) a fiscalização - arbitrária dos órgãos ambientais. Digo arbitrária, pois é comum, fiscais órgãos estatais aplicar multas indiscriminadamente e, forçar, de alguma forma, um "acerto por fora"; (c) a forte degradação do solo, motivada principalmente pela erosão laminar e em sulcos; (d) as queimadas das pastagens que chegam a atingir as sedes das fazendas, provocando danos materiais e, inclusive, a morte de animais (Figura 6).

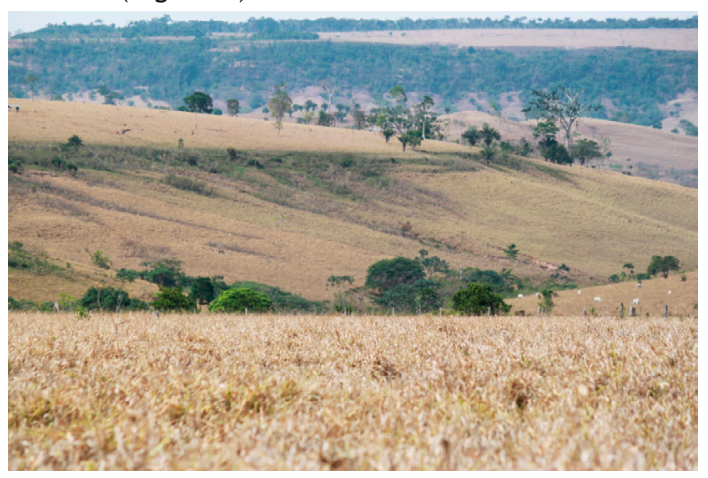

Figura 6

Cuja localização está georrefenciada - $15^{\circ} 08^{\prime} 18.9^{\prime \prime}$ S e $58^{\circ} 44^{\prime} 36.8^{\prime \prime}$ W - Altitude: $458 \mathrm{~m}$. e que se presta como "paisagem indicadora" de dinâmicas biostásicas/resistásicas das vertentes mais íngremes da compartimentação das sucessivas Chapadas: a partir dos níveis altimétricos mais elevados da Chapada dos Parecis $(750$ a $800 \mathrm{~m})$ em direção ao Vale do Guaporé-Jauru (250-400m).

Fonte: Passos, 06/04/2016. 
0 problema das queimadas tende a se agravar, visto que as condições climáticas regionais, associadas ao manejo impróprio de muitas parcelas rurais colocam em risco de queimadas generalizadas, que podem fugir do controle, apesar de toda a fiscalização dos órgãos ambientais, notadamente do Instituto Chico Mendes/ICMBIO e, claro, da consciência dos próprios proprietários.

Apesar dos elevados índices pluviométricos registrados para a região, pode-se afirmar que a concentração ao longo do período que vai de outubro a março e a acentuada redução no período que vai de abril a setembro, têm reflexos negativos sobre a dinâmica da paisagem e, claro, sobre as atividades antrópicas. É bom lembrar que, no período seco, as condições de forte insolação e elevadas temperaturas mantêm-se praticamente idênticas àquelas da estação chuvosa e quente, sendo o referido período agravado pela prática de se refazer os pastos à base de queimadas, notadamente durante os meses de agosto e setembro.

A região foi submetida ao rigor de 123 dias sem chuvas (abril-setembrol1994), agravado pelas queimadas gerais, levando os moradores e proprietários a um estado de desolação total. É bom lembrar que períodos idênticos e, até mais prolongados sem chuvas, ocorreram em anos anteriores e posteriores a essa data.
No período seco, os processos morfogenéticos relacionados ao escoamento subsuperficial mantêm-se inativos. É nesse período que o processo de assoreamento e de desperenização dos córregos e ribeirões melhor se evidencia (Figura 7).

A Figura 11 se presta como "paisagem indicadora" da dinâmica morfogenética muito ativa em superfícies neogênicas, após o desmatamento da área.

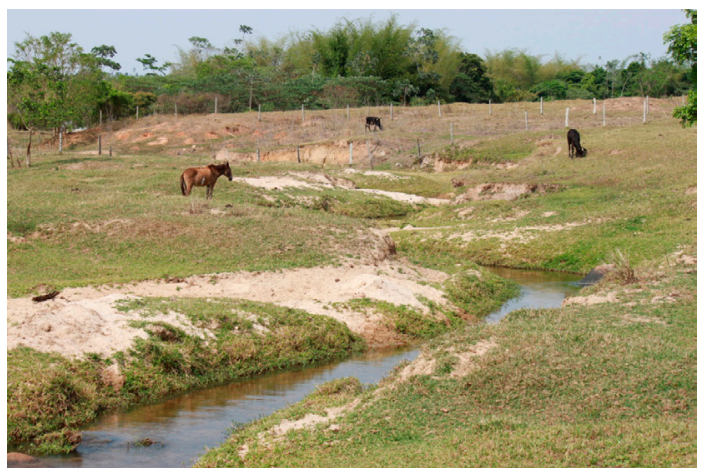

Figura 7

Córrego, afluente do rio Jauru, cuja localização (da foto) está geor referenciada - 15: $15^{\circ} 08^{\prime} 05.5^{\prime} \mathrm{S}$ - 58 $46^{\prime} 18.1^{\prime \prime} \mathrm{W}$ - Altitude: $451 \mathrm{~m}$ e que se presta como "paisagem indicadora" do processo erosivo de fundo de vale motivado por algumas variáveis: (a) desmatamento indiscriminado; (b) regime de chuvas torrenciais; (c) litologia de rocha granítica de pouca resistência aos efeitos de água de escoamento superficial.

Fonte: Passos, 07/04/2016.

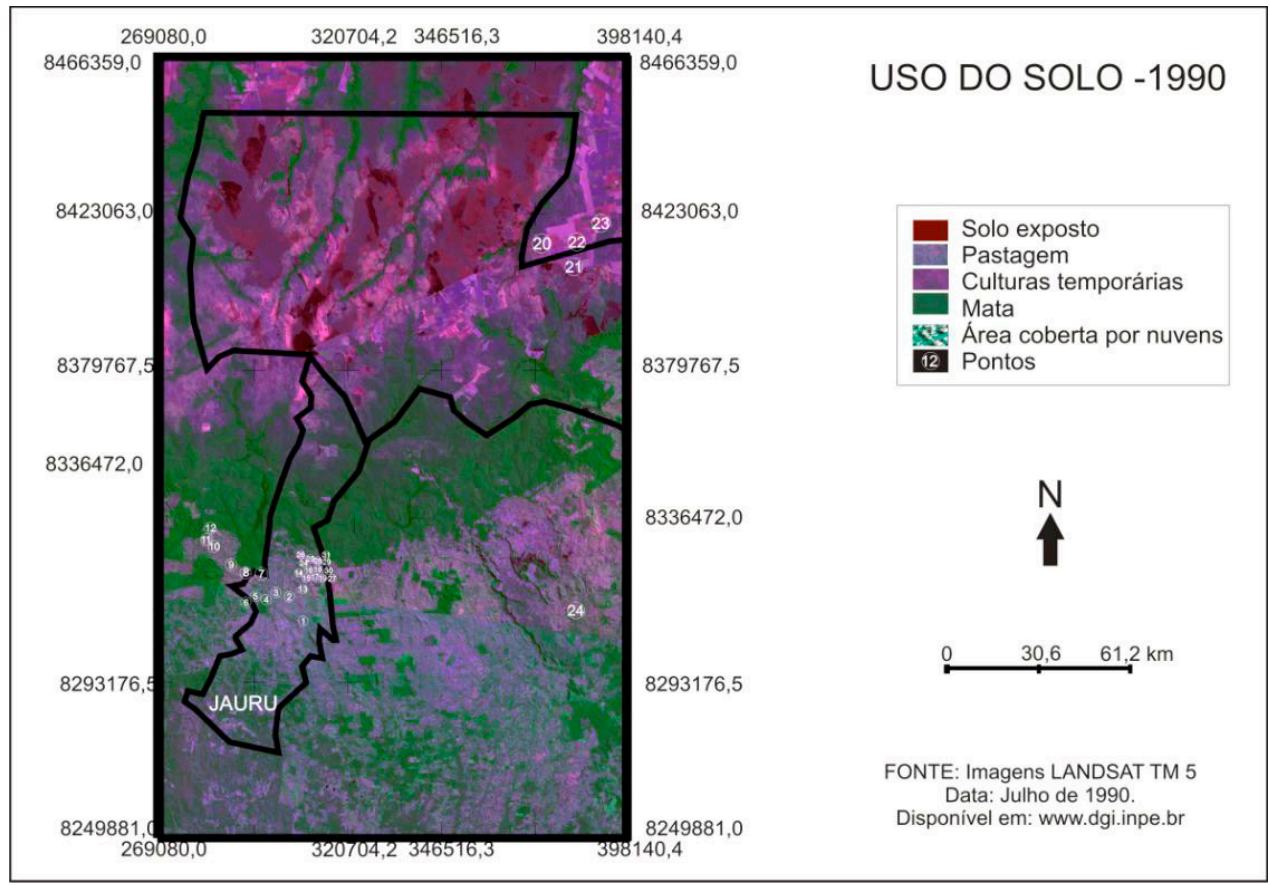

Figura 8

Uso da terra no sudoeste do Mato Grosso: município de Jauru e Chapada dos Parecis - 1990.

Fonte: Passos, 2015. 


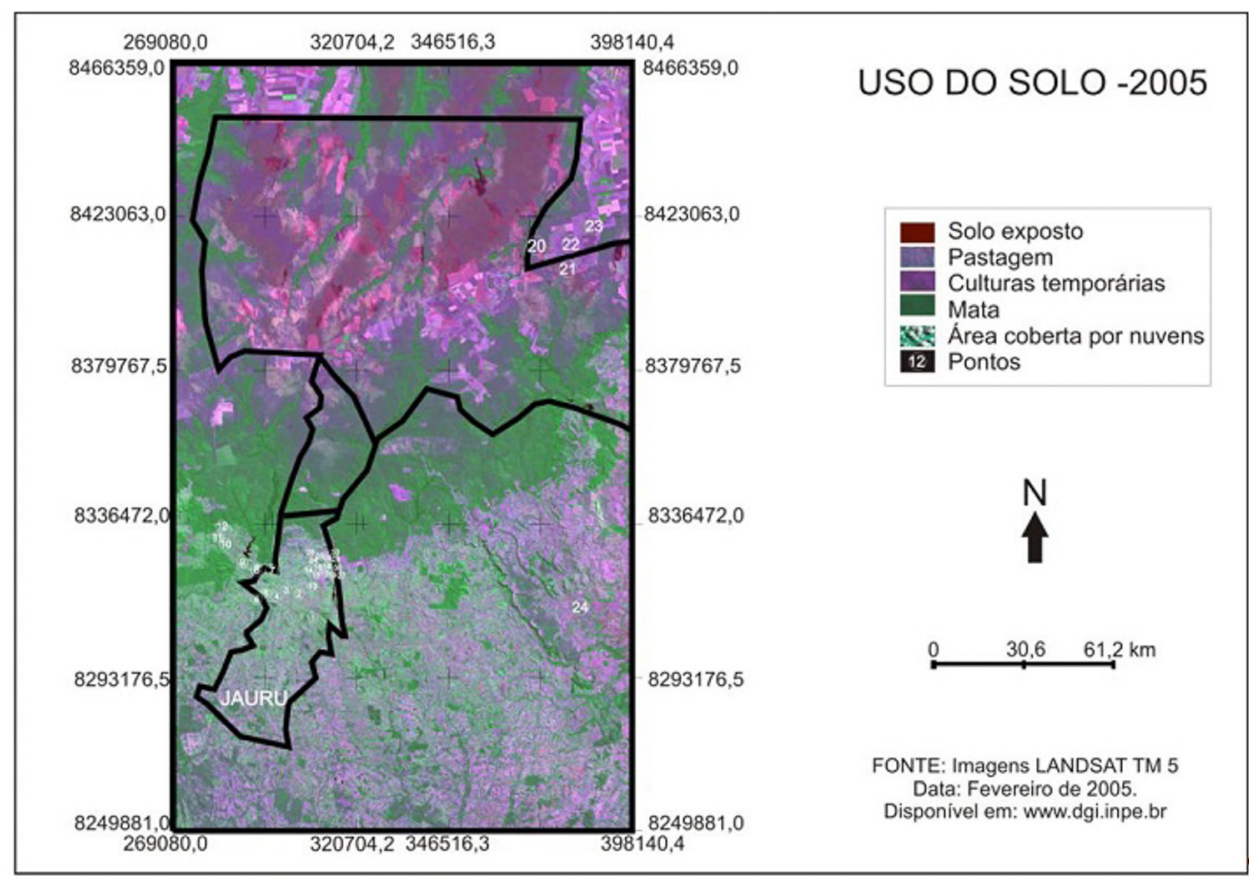

Figura 9

Uso da terra no Sudoeste do Mato Grosso: município de Jauru e Chapada dos Parecis - 2005.

Fonte: Passos, 2015.

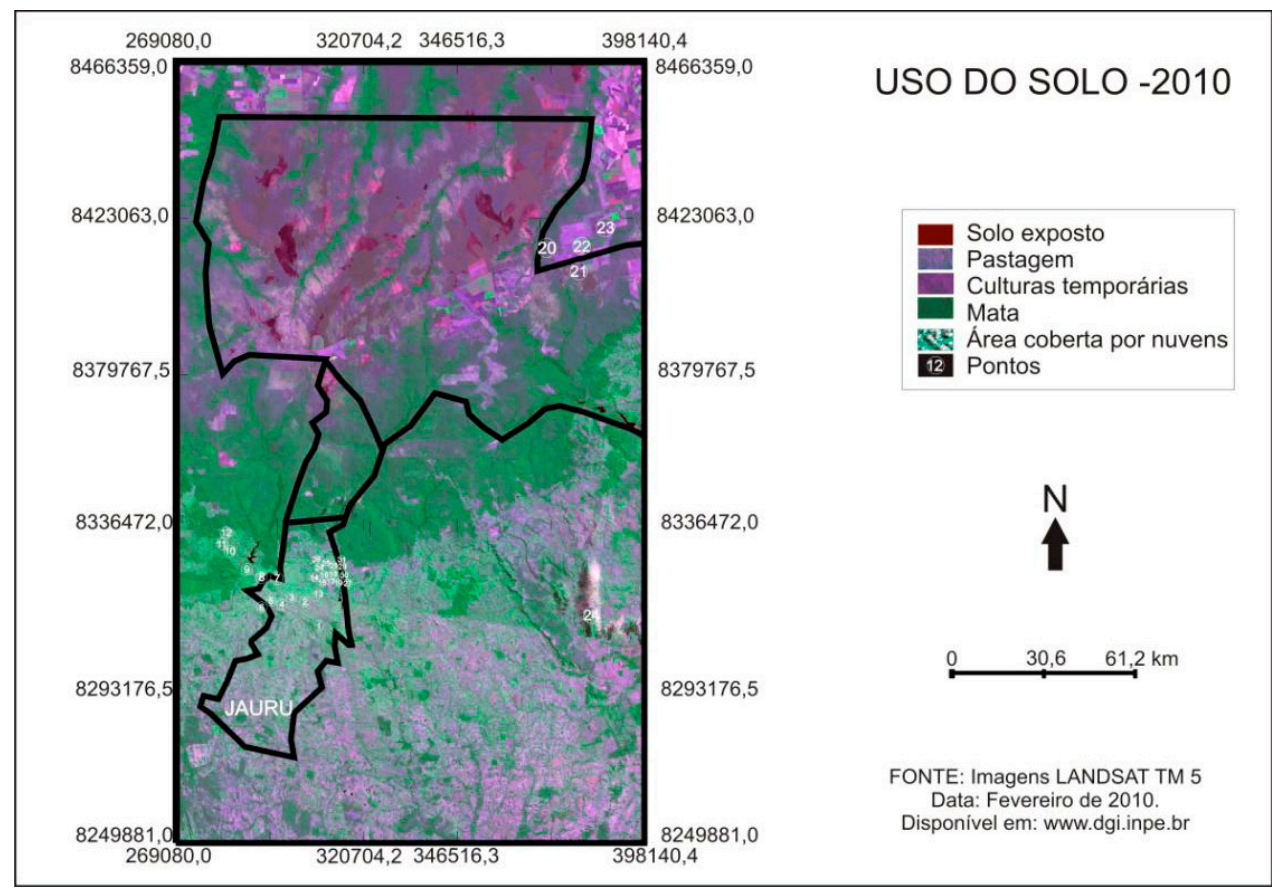

Figura 10

Uso da terra no sudoeste do Mato Grosso: município de Jauru e Chapada dos Parecis - 2010.

Fonte: Passos, 2015. 
Todas essas fotos estão plotadas sobre imagens Landsat e fazem parte do meu arquivo "Paisagens indicadoras", de modo a permitir o acompanhamento da evolução das dinâmicas observadas em cada uma delas.

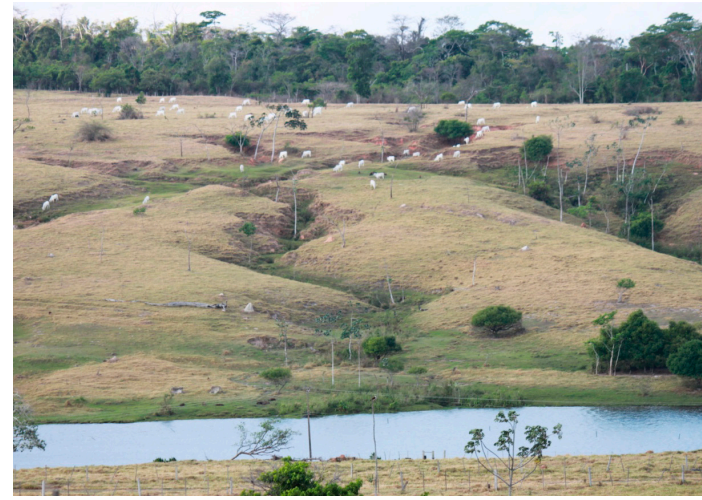

Figura 11

Área localizada próximo da sede da Fazenda Guapé/município de Jauru-MT, georreferenciada - 12: 0283362 e 8335211 - 571MT - SW-NE e que se presta como "paisagem indicadora" de. incisões fluviais em superfície neogênica, cujo processo erosivo foi acelerado após desmatamento.

Fonte: Passos, 07/04/2016.

\section{A abordagem biogeográfica para identificação de} paisagens indicadoras

As vertentes platina (sul) e amazônica (norte) apresentam contrastes quer de natureza morfológica quer de natureza vegetal. Na face voltada para a Amazônia, a topografia é suave, sobressaindo os espigões mais elevados, com uma altitude média de 500 metros. No quadro botânico, há predomínio das espécies vegetais amazônicas sobre as espécies vegetais de cerrado. Já na vertente oposta, o planalto avança para o sul em verdadeiras lombadas, onde se destacam cristas pontiagudas, sob a forma de chapadões alongados, revestidos com cerrado.

A complexidade da exploração biológica nessa área de transição entre as duas grandes bacias hidrográficas da América do Sul, Amazônica (norte) e Platina (sul), é reflexo das condições paleoclimáticas e climáticas atuais e, claro, dos demais elementos de estruturação da paisagem. Dito de outra forma, essa complexidade se sustenta no potencial ecológico e se traduz na importância que a vegetação tem como elemento paisagístico e principal promotor da dinâmica dos geocomplexos.

No que se refere ao Vale do Guaporé-Jauru, é difícil estabelecer a preponderância de um dos fatores que intervêm na criação da paisagem. As influências se diversificam de tal maneira que fazem da paisagem um perfeito "nó" das forças que intervêm no meio. Assim, por exemplo, há que se reconhecer a influência da vegetação na organização da paisagem do sudoeste do Mato Grosso; no entanto, não se deve desvalorizar a influência dos fatores climáticos, geológicos etc. e, inclusive, da ação antrópica.

No início da década de 1950, as Companhias Colonizadoras chegaram a essa porção do território mato-grossense. Mas foi, sobretudo, a partir da chamada Operação Amazônia, desencadeada a partir de 1965, que essa região vai vivenciar duas frentes pioneiras diversas: (1) uma dirigida e mais capitalizada vai atuar nas áreas de chapadões revestidos com cerrados, priorizando, essencialmente, o cultivo da soja; (2) outra, mais espontânea e, de certa forma, caótica, dirige-se para as áreas de florestas do Vale do Alto Guaporé. Do processo de ocupação, resultante da ação de ambas, resulta um quadro de impactos socioambientais consideráveis, tendo no desmatamento indiscriminado uma das suas variáveis mais expressivas.

No sentido de melhor explicar as principais formações vegetais que na atualidade existem no "sudoeste do Mato Grosso", selecionamos quatro lotes, cujas informações biogeográficas foram recoIhidas nas fichas de campo e representadas graficamente por meio das pirâmides de vegetação.

A comparação entre as pirâmides permite algumas interpretações a respeito da evolução/dinâmica da vegetação e, ainda, fornece parâmetros imprescindíveis à aplicação da teledetecção ao estudo da paisagem. Por exemplo, uma floresta (Figura 12) se distingue perfeitamente de uma formação de cerrado (Figura 13) ou de uma "vegetação serrana" (Figura 14) pela importância relativa de seus estratos. Uma "vegetação de capoeira" com estrato rasteiro bem desenvolvido se diferencia, muito claramente, de uma área de pastagem com "paliteiros" (Figura 15).

$\mathrm{Na}$ análise da estrutura vegetal, levamos em conta o número de estratos e o modo de agrupamento das plantas para, então, representá-la cartograficamente. Mas é, sobretudo, a interpretação dinâmica que deve reter a atenção do biogeógrafo. As pirâmides traduzem perfeitamente a concorrência entre as espécies. Nas formações florestais, os estratos superiores sufocam as plantas dos estratos inferiores, interferindo na evolução da vegetação. Ao contrário, as áreas desmatadas e posteriormente abandonadas são invadidas por espécies subarbustivas muito competitivas que, ao recobrirem o solo, atuam no sentido de protegê-lo da erosão. As áreas 
de pastagens têm uma dinâmica determinada, em grande parte, pela capacidade do potencial ecológico resistir às mudanças introduzidas pelo homem e, ainda, pela resistência da exploração biológica, uma vez submetida ao desmatamento, queimadas anuais e manejo da área. Regra geral, as áreas de floresta tropical do Alto Guaporé-Jauru passam do estágio de biostasia para o de resistasia muito abruptamente. Ao contrário, as áreas de transição, com ocorrência elevada de palmeiras, sobretudo de babaçu, apresentam capacidade elevada de regeneração/rebrotamento, atuando, dessa forma, no sentido da manutenção de uma dinâmica menos negativa da paisagem. No “Sudoeste do Mato Grosso", as capoeiras estão restritas aos geótopos no qual o lençol freático ainda se mantém próximo da superfície.

0 afundamento do lençol freático, observado 4-5 anos após o desmatamento, é o maior obstáculo a uma dinâmica progressiva da vegetação.

Os levantamentos fitossociológicos (Abundância-Dominância e Sociabilidade) foram anotados nas "fichas biogeográficas" e representados cartograficamente nas Pirâmides de Vegetação, e se prestam como "paisagens indicadoras", notadamente pela ocorrência de exemplares jovens no interior da floresta e do próprio cerrado nas unidades de paisagem onde o lençol freático ainda se mantém próximo da superfície - revela que essas áreas mantêm uma dinâmica progressiva ou em equilíbrio. Observando-se as Figuras 12 a 15, fica fácil seguir a concorrência entre os diferentes estratos. Por exemplo, na Figura 12 (Floresta Estacional Semidecidual), observa-se o triunfo absoluto do estrato arbóreo, contínuo e denso que, filtrando a luz, limita a extensão do sub-bosque. Pelo contrário, quando o estrato arbóreo se apresenta menos denso, permitindo a penetração da luz solar, favorece o desenvolvimento dos estratos inferiores.

As pirâmides de vegetação permitem fazer ideia melhor das relações entre a vegetação e a erosão "biológica". Do ponto de vista estrutural, é clássico se opor as formações vegetais abertas às formações vegetais fechadas. A "Floresta Estacional Semidecidual" (Figura 12) exerce um papel significativo no sentido de evitar os diversos níveis de erosão. As plantas isoladas ou em tufos, próprias da vegetação de Cerrado Parque (Figura 13) e, até mesmo das pastagens artificiais (Figura 15), deixam entre si largas placas de solo nu expostas à erosão. Aí as ravinas de alguns decímetros se desenvolvem livremente. O escoamento do tipo areolar domina as vertentes menos inclinadas e impede visivelmente a germinação da vegetação. Sobre as vertentes mais inclinadas $(>10 \%)$, passa-se progressivamente para ravinas de escala métrica que são já uma manifestação da erosão "geomorfológica". Essas situações mais agudas estão presentes nas vertentes inclinadas e com "superfície neogênica". Aqui, a erosão atinge níveis comprometedores, devido à escala de atuação dos agentes morfogenéticos (Figura 11).

Para se estudar o equilíbrio de uma formação vegetal e suas relações com a erosão, é preciso, pois, considerar, em primeiro lugar, a "abertura" ou a "fechadura" do tapete vegetal ao nível do solo. Na zona tropical úmida, as formações abertas secundárias associadas às séries regressivas agudizam o já delicado problema das relações dinâmicas entre a vegetação e a erosão “biológica”. A erosão é um fator de mobilidade ecológica. Os ravinamentos provocam o desaparecimento do solo, a migração dos substratos coloidais e a seca biológica do substrato. O complexo absorvente se empobrece. A vegetação não pode mais se regenerar normalmente. As espécies exigentes desaparecem. 0 tapete vegetal se modifica. A floresta abatida não se reconstitui e deixa o espaço livre à erosão. Os elementos climáticos se "transformam em agentes morfogenéticos". O super uso e os incêndios abrem o tapete vegetal, os solos são erodidos e a evolução da vegetação, certamente irreversível, resulta em formações secundárias constituídas por espécies menos exigentes ecologicamente. Muitas espécies, estabelecidas em fases de otimum climaticum, não têm "valência ecológica" suficiente para resistir às novas condições ambientais. A erosão torna-se então um rigoroso "fator-limitante".

Do ponto de vista biogeográfico, a erosão aparece como um fator ecológico essencial que se tem negligenciado muito. Pode haver erosão "biológica" sob floresta, desde que os estratos inferiores sejam abertos. Do ponto de vista geomorfológico, é possível compreender melhor como a erosão pode se desencadear de maneira epidérmica sob cobertura vegetal e se estender a seguir até a destruição mais ou menos completa da vegetação.

Essa marcha lenta, no seio de uma formação vegetal em desequilíbrio ecológico, poderá nos ajudar a melhor compreender como se efetua a passagem de fases biostásicas às fases resistásicas.

As pirâmides de vegetação (Figuras 12 a 16) apresentadas a seguir, têm o objetivo de sustentar o exposto acima. 


\section{Floresta Estacional Semidecidual}

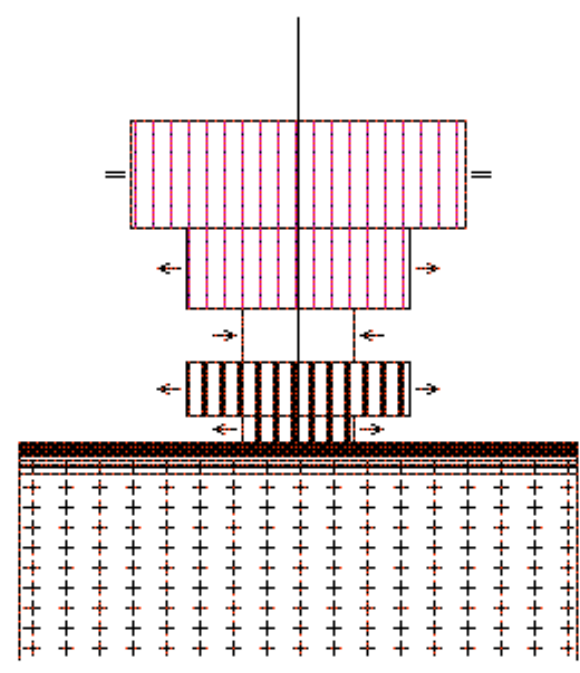

Fazenda Guape

Jauru

Mato Grosso - Brasil

No chave: guape

Data.... : 9-IX-94

\author{
Latitude: $15^{\circ} 10^{\prime} \mathrm{S}$ \\ Long itude: $588^{\circ} 57$ ' \\ Temp. media anual: $23{ }^{\circ} \mathrm{C}$ \\ Prec. anual..... : $1600 \mathrm{~mm}$ \\ Altitude........ $285 \mathrm{~m}$. \\ Sem inclinaçāo = superficie plana \\ Exposiçāo.......: indiferente
}

Complexo Xingu

Figura 12

Floresta Tropical Semidecidual do Alto Guaporé/MT. Pirâmide construída a partir de Levantamentos Fitossociológicos realizados em 9/11/1994. Domínio: Tropical. Série da floresta climática submontana. Georreferenciamento: 0289058 e 8326793 UTM - HUMUS: Matéria orgânica sem decomposição(folhas secas e raízes). Altitude: $258 \mathrm{~m}$. Inclinação: 1\%. Exposição: Indiferente. Clima: Tropical, quente e subúmido. Precipitação anual: 1500 a $1750 \mathrm{~mm}$ com caráter estacional: seca no inverno (de 4/6 meses) e chuvas no verão (5/7 meses). Temperatura média anual de + ou - $23^{\circ} \mathrm{C}$ com altas oscilações térmicas diárias no inverno. Microclima: umidade elevada pela ação do dossel arbóreo. Rocha Mãe: Embasamento cristalino de rochas metamórficas que bordejam pelo Sul a Chapada dos Parecis.Complexo Xingu, próximo do contacto com as rochas sedimentares mesozóicas. Erosão Superficial: Desprezível. Ação Antrópica: Atualmente nenhuma, porém há sinais de retirada de madeira. Dinâmica de Conjunto: Com o cessar da exploração madeireira (“mogno"), observa-se que as “clareiras" começam a ser recuperadas por exemplares jovens. 0 conjunto da formação, portanto, está em equilíbrio com uma clara tendência à progressão por regeneração.

Fonte: Passos, 8/04/2016.

Interpretação biogeográfica: esbôço estrutural e dinâmica da vegetação

A pirâmide oferece uma visão expressiva do tapete vegetal. É suficiente comparar algumas pirâmides, conforme fizemos no presente estudo. As formações vegetais abertas (cerrado) se opõem às formações vegetais fechadas (floresta).

Partindo de uma análise da estrutura vegetal, é possível classificar as formações segundo o nível de recobrimento, fazendo intervir o número de estratos (mono ou pluri-estratos).

A interpretação dinâmica deve reter a atenção do biogeógrafo. As pirâmides traduzem perfeitamente a concorrência entre as espécies. Nas florestas, as espécies do estrato superior sufocam as dos estratos inferiores. As pirâmides permitem, pois, seguir a concorrência entre os diferentes estratos, e seguir, também, a evolução no interior de um mesmo domínio biogeográfico.

\section{Interpretação geomorfológica}

Entre os "fatores ecológicos", "corretivos ecológicos" e outros "fatores limitantes", os botânicos incluem a inclinação da vertente, o solo, o microclima etc.; isto é, os fenômenos que servem para definir a estação vegetal ou biótopo como meios estáveis. Muito pouco se fala da questão erosão. Para evitar as confusões e as interpretações abusivas, é bom definir exatamente este termo. Salvo caso excepcional, não se trata, aqui, da erosão "geológica", ou melhor, "geomorfológica" criadora do relevo, mas de uma erosão do tipo epidérmico que só interessa à "cobertura viva das vertentes", isto é, o solo, a micro-fauna e a vegetação. Por esta razão se pode qualificá-la de "biológica”. Entre a erosão "biológica” e a erosão "geomorfológica” há somente uma diferença de intensidade; a segunda sendo o prolongamento natural da primeira. Mas a escala dos fenômenos não é a mesma. Colocamos-nos, aqui, sobre o plano biogeográfico, portanto, mais próximo do plano histórico do que do plano geológico. 
cerrado

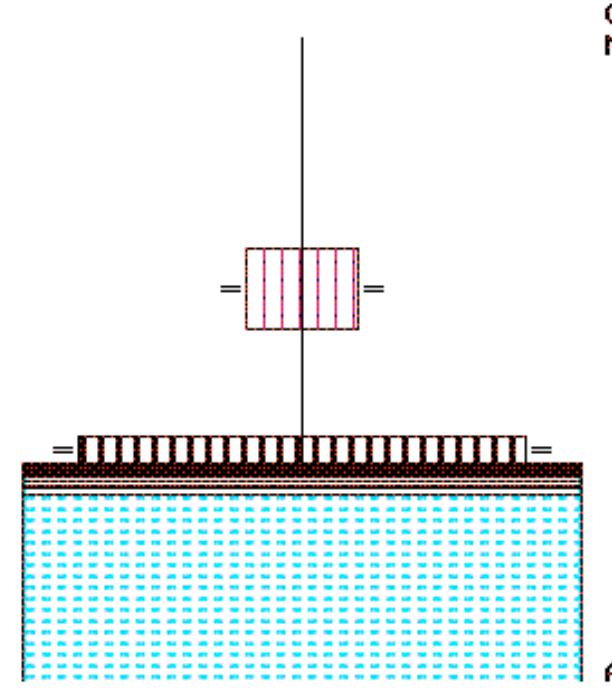

Fazenda Branca

No chave: Branca

Data... . : 08-I-94
Campos Novos dos Parecis
Mato Grosso - Brasil

\author{
Latitude: 14 '45'S \\ Longitude: $58^{\circ} 50^{\prime} W$ \\ Temp. media anua l: $24{ }^{\circ} \mathrm{C}$ \\ Prec. anual.....: $1650 \mathrm{~mm}$ \\ Altitude........ $740 \mathrm{~m}$. \\ Sem inclinaçāo = superficie plana \\ Exposiçāo...... indiferente
}

\begin{tabular}{|c|c|}
\hline & SOC IAB IL IDADE \\
\hline & 1 Individuos isolados \\
\hline & 2 Plantas em grupos de 2 ou 3 \\
\hline & 3 Em grupo \\
\hline & 4 11. densa pouca estendida \\
\hline & $\begin{array}{l}5 \text { Populaçāo continua e densa } \\
\text { DIMAMICA DOS ESTRATOS }\end{array}$ \\
\hline & Equilibrio \\
\hline & Progressāo $\rightarrow \leftarrow$ Regressāo \\
\hline
\end{tabular}

Arenito

Figura 13

Formação vegetal de Cerrado Parque. Fazenda. Branca - Chapada dos Parecis/MT. . Pirâmide construída a partir de Levantamentos Fitossociológicos realizados em 8/01/1994.

Humus: Pouco significativo. Altitude: $740 \mathrm{~m}$. Inclinação: 1\%. Exposição: Indiferente. Clima: Tropical, quente e subúmido. Precipitação: 1.500mm a $1.700 \mathrm{~mm}$. O período seco é bem marcado. As temperaturas médias são mais altas entre $24^{\circ} \mathrm{C}$ e $25^{\circ} \mathrm{C}$ e a umidade relativa reduz-se a valores abaixo de $60 \%$ nos meses de estiagem. Os meses mais quentes são os compreendidos entre agosto e novembro, quando a radiação é intensa e o ar está seco; com a chegada das chuvas a temperatura diminui. Microclima: A vegetação aberta ao lado da forte insolação reduz possíveis diferenciações microclimáticas. Rocha-mãe: Arenitos do Grupo Parecis. Solo: Areia Quartzosa (relevo plano). Erosão: Ausente. Contudo, acreditamos que a eliminação da cobertura de cerrado para a implantação de extensos projetos agropecuários sustentados, principalmente, na monocultura da soja cujo manejo exige elevado índice de mecanização, desencadeará um rápido processo de erosão laminar e em sulco com assoreamento das nascente localizadas no "segundo degrau" da Chapada dos Parecis. Ação Antrópica e Dinâmica de Conjunto: A construção da BR-364, acompanhada do avanço da fronteira agrícola verificado com maior intensidade a partir da segunda metade dos anos 70, "reorganizou" o espaço na Chapada dos Parecis: invasão de reservas indígenas, especulações as mais diversas pela posse da terra, "modernização" agrícola, transformação radical da paisagem.

Fonte: Passos, 09/04/2016.

Esta situação de equilíbrio coloca o delicado problema das relações dinâmicas entre a vegetação e a erosão "biológica". A erosão é um fator de mobilidade ecológica. Os ravinamentos, as decapagens, provocam o desaparecimento do solo, a migração dos substratos coloidais, a seca biológica do substrato etc. O complexo absorvente se empobrece. A vegetação não pode se regenerar normalmente. As espécies mais exigentes desaparecem. 0 tapete vegetal se modifica.

Nas relações entre uma formação vegetal e a erosão "biológica" é preciso distinguir dois casos:

(a) a vegetação prevalece sobre a erosão. Uma formação fechada, climácica ou não, dá poucas chances à erosão. Após uma catástrofe natural (incêndio) ou mais frequentemente de uma intervenção humana, a cobertura vegetal se degenera, então, a erosão pode aparecer e se desenvolver. Mas ao curso de um tempo mais ou menos longo e por dinâmica natural, a vegetação vai recolonizar o espaço vazio; primeiramente por intermédio de espécies especializadas, que preparam o retorno da formação clímax. A erosão "biológica" conserva, então, o caráter de um acontecimento excepcional. É o caso da maioria das formações vegetais das zonas temperadas e tropical úmida.

b) a erosão prevalece sobre a dinâmica vegetal e determina a distribuição e a mobilidade das formações vegetais. Nas regiões áridas e semi-áridas encontram-se numerosos exemplos desta subordinação da vegetação à erosão.

A Geografia Física, pelo menos aquela que se pratica habitualmente, repousa sobre uma considerável contradição interna: sintética por seu objeto, ela não o é frequentemente no seu método. Ela tenta entender os conjuntos naturais a partir de passos setoriais (geomorfologia, climatologia, hidrologia, biogeografia...). A síntese intervém quase sempre a posteriori... Aliás, trata-se mais frequentemente de uma síntese com finalidade geomorfológica que de uma apreensão global da paisagem. 


\section{Vegetacao serrana}

\author{
No chave: Castical \\ Data... . : 14-I-94 \\ Fazenda Aracatuba \\ Jauru \\ Mato Grosso - Brasil
}

\author{
Latitude: $15^{\circ} 5^{\prime} \mathrm{S}$ \\ Longitude: $59^{\circ} 15^{\prime}$ \\ Temp. media anual: $24^{\circ} \mathrm{C}$ \\ Prec. anual .....: $1600 \mathrm{~mm}$ \\ Altitude.......: $470 \mathrm{~m}$. \\ Inclinaçāo.....: $9^{\circ}$
}

Complexo Xingu

\section{Figura 14}

Vegetação 'serrana' - Serra do Castiçal - Fazenda Araçatuba - Jauru/MT. . Pirâmide construída a partir de Levantamentos Fitossociológicos realizados em 14/01/1994.

Formação: “Vegetação Serrana"/Chavascais - Série de Floresta Climácica Submontana. - Georreferenciamento: 0286650 e 8331991 UTM Humus: inexpressivo. Altitude: $470 \mathrm{~m}$. Inclinação: $16 \%$. Exposição: N-NW. Clima: Tropical, quente e subúmido. Precipitação média anual entre $1.500 \mathrm{~mm}$ e $1.750 \mathrm{~mm}$, com caráter estacional: seca no inverno (4/6 meses-maio/ setembro) e chuvas no verão (outubro-abril/ 5-7 meses). Temperatura média anual de + ou $-23^{\circ} \mathrm{C}$, com altas oscilações térmicas diárias no inverno. Microclima: relativamente seco, devido à exposição topográfica, inclinação da vertente, solo pedregoso e estrato arbóreo "aberto". Rocha-mãe: embasamento cristalino de rochas metamórficas que bordejam pelo Sul a unidade de relevo da "Chapada dos Parecis". Complexo Xingu. Solo: Litossolo. Erosão superficial: sinais de "incisões fluviais" (superfície neogênica). Ação Antrópica: ausente. Contudo, observa-se que as pastagens artificiais avançam em sua direção. Dinâmica de Conjunto: 0 conjunto da formação vegetal serrana está em equilíbrio. Destaca-se a presença do babaçu, espécie de alta valência ecológica que está "controlada" pela presença das demais espécies vegetais.

Fonte: Passos, 10/04/2016.

\section{Considerações finais}

O termo "projeto" significa, na linguagem comum, a primeira intenção de uma ação futura que deverá ser seguida de ações concretas para a sua realização. Na linguagem dos arquitetos, ele designa o conjunto de plantas e de cálculos técnicos que representam o conjunto de procedimentos que devem ser adotados para a construção do edifício. A arquitetura, portanto, introduziu no termo "projeto" a noção fecunda de uma tentativa progressiva que começa com a definição inicial da intenção, da ideia, para em seguida, se dedicar nas escolhas formais, materiais e técnicas necessárias à sua realização. Neste sentido, o projeto é um processo intelectual caminhando à parte de um desenho inicial e o acompanhando, em todas as etapas: de sua definição, até a sua realização material.

No domínio da paisagem, o termo "projeto" herda o caráter evolutivo do projeto de arquitetura: o projeto de paisagem é antes um processo para motivar uma situação nova. Mas, o projeto de paisagem introduz uma exigência suplementar: ele é sempre inscrito, qualquer que seja a sua escala, na dimensão de uma realidade territorial, isto é, numa situação de uma grande complexidade que impõe, não somente na concepção do projeto, como o desenvolvimento coerente de uma ideia... até a sua realização, mas também de situar esta tentativa em relação aos sistemas dinâmicos (naturais, culturais, econômicos e sociais) que fundam a realidade territorial.

A complexidade presente no campo de ação dos paisagistas introduz, pois, uma exigência de dupla competência: aquela da dinâmica dos sistemas paisagísticos próprios de cada território e aquela de uma atitude para conceber e realizar situações espaciais inéditas. A originalidade do projeto paisagem repousa sobre sua capacidade para associar, em torno de uma visão forte da mutação do espaço territorial, os diferentes registros operacionais: 


\section{Pastagem com paliteiros}

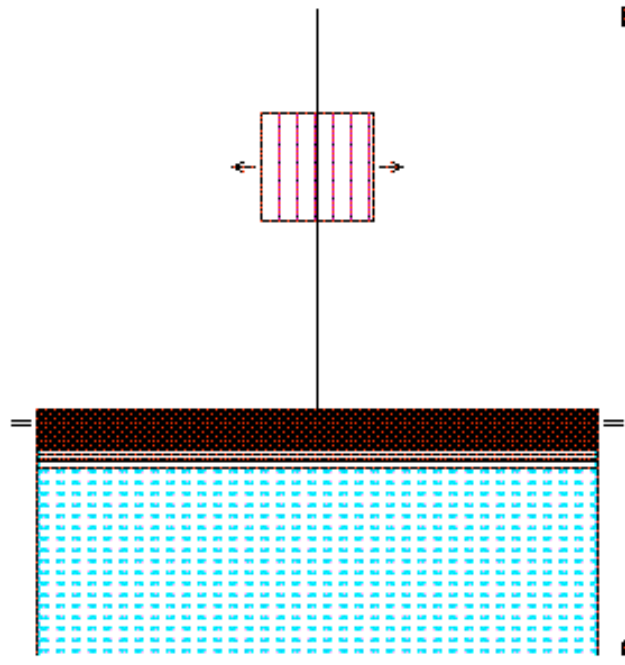

Fazenda Barreirao
Jauru

No chave: Barreirao

Data.... : 13-I-94

\author{
Mato Grosso - BR
}

Figura 15

Vegetação antrópica/pastagem com "paliteiros” - Fazenda Barreirão Jauru/MT. . Pirâmide construída a partir de Levantamentos Fitossociológicos realizados em 13/01/1994.

Vale do Guaporé-Jauru/Sudoeste do Mato Grosso Domínio Tropical - Série de Floresta Tropical de Transição. Georreferenciamento: 0311511 e 8326875 UTM - Altitude: $340 \mathrm{~m}$. Inclinação: 1\%. Exposição: Indiferente. Clima: Idem ao lote anterior. Microclima: As condições pedológicas (solo arenoso e permeável) determinam um microclima seco, não favorável às relações solo-planta. Rocha-mãe: Idem ao lote anterior. Solo: Latossolo Vermelho-Amarelo. Erosão: No lote, propriamente, não se observam sinais de ravinamento ou de outro aspecto resultante de erosão em sulco. Contudo, a erosão laminar é muito acentuada, sobretudo, no momento das primeiras chuvas/tempestades que ocorrem no início da estação chuvosa (setembro-outubro). Tal fenômeno se deve às queimadas, para "refazer" os pasto e também, ao próprio ciclo da pastagem que praticamente seca ao final da estação desfavorável. Ação Antrópica e Dinâmica de Conjunto: A área foi desmatada, no início da década de 70, à base de moto-serra e "caixa de fósforos", eliminando, de forma radical, a biota tropical. Os exemplares do estrato arbóreo ainda existentes, certamente, serão eliminados pelas futuras queimadas. O nível de erosão laminar e, mesmo, de vossorocamento (em pontos de menos resistência litológica/superfícies neogênicas...), já é motivo de grande preocupação, exigindo maiores cuidados no sentido de manter a capacidade de apascentamento (1-1,5 cabeças/hectare) e o "controle" das voçorocas.

Fonte: Passos, 09/04/2016.

identificação dos conjuntos territoriais pertinentes, compreensão e mobilização das dinâmicas em ação neste território, concepção de situações paisagísticas, formulação de respostas espaciais e formais coerentes nas diferentes escalas, implementação de modos de ações muito diversificados. É essa dimensão que justifica a utilização de fotos e de imagens de diferentes momentos..., pois são esses diferentes tempos que se prestam como referências para se diagnosticar a evolução da paisagem, ou seja, justificar a "paisagem indicadora" como uma ferramenta de observação sistemática.

A espacialização das paisagens-indicadoras pelo tratamento de imagens de satélite contribui para a apreensão de um nível de informação regional confiável e coerente para a produção de cartas que permitem compreender e avaliar o estado dos territórios e acompanhar suas mudanças? Estamos cientes de que uma resposta mais confiável, a esta questão, requer o acompanhamento das dinâmicas territoriais/ mudanças paisagísticas por um período mais longo.
E mais: para que a paisagem-indicadora torne-se um indicador confiável das mudanças socioambientais, motivadas pelos diversos agentes e sujeitos envolvidos nos processos de definições e de redefinições das dinâmicas socioambientais e, portanto, se preste ao melhoramento dos conhecimentos dos meios e das sociedades que os habitam e constitua um dos suportes das proposições para a ajuda da decisão em matéria de políticas de desenvolvimento sustentável, é necessária a expansão do período dessa investigação.

Os objetivos e interesse científico de um projeto centrado na "paisagem indicadora" requer a confrontação dos procedimentos metodológicos com parâmetros “consagrados" por outros grupos de pesquisas $^{3}$ de modo a permitir afinar e ajustar o guia metodológico proposto, a fim de torná-lo operacional nos diversos contextos territoriais; e mais: é preciso avaliar/testar a paisagem como uma entrada e uma

\footnotetext{
3 Université de Toulouse Le Mirail; Université de Rennes 2, Université d'Avignon - França.
} 
FLORESTA ESTACIONAL SEMIDECIDUAL RECEM DESMATADA

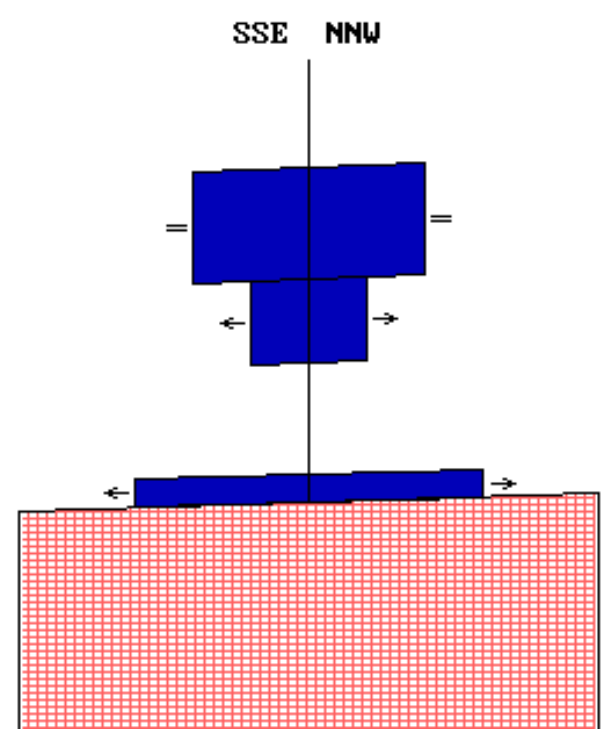

FAZENDA RIO BONITO

№ chave: 05

JAURU

MT/BRASIL

\author{
Latitude: $15^{\circ} 20^{\prime} \mathrm{S}$ \\ Long itude: $58^{\circ} 50^{\prime} W$ \\ Temp. media anual: $23^{\circ} \mathrm{C}$ \\ Prec. anual.....: $1750 \mathrm{~mm}$ \\ Altitude....... $285 \mathrm{~m}$. \\ Inclinaçāo...... 2 :
}

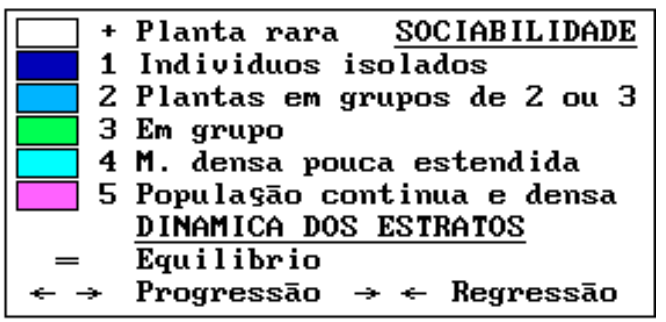

EMBASAMENTO CRISTAL INO

Figura 16

Floresta estacional semidecidual - recém desmatada. Fazenda ribeirão Bonito, município de Jauru/MT. . Pirâmide construída a partir de Levantamentos Fitossociológicos realizados em 10/09/1994.

Formação: Floresta Estacional Semidecidual. Georreferenciamento: 0299709 e 8317225 UTM. Altitude: 597 metros. Humus: Matéria orgânica sem decomposição. Altitude: 330 m. Inclinação: 7 \%. Exposição: N-NW. Clima: Tropical, quente e subúmido. Precipitação anual: 1500 mm a 1750 mm com caráter estacional: seca no inverno (de $4 / 6$ meses) e chuvas no verão ( $5 / 7$ meses). Temperatura média anual de + ou $-23^{\circ} \mathrm{C}$ com altas oscilações térmicas diárias no inverno. Microclima: menos úmido do que o observado nos lotes anteriores, devido à exposição N-NW da vertente e, também, pela menor capacidade de retenção hídrica, devido à inclinação e as condições pedo-litológicas. Rocha-mãe: Embasamento cristalino de rochas metamórficas que bordejam pelo Sul a Chapada dos Pareacis. Complexo Xingu. Solo: Podzólico com cascalho. Erosão superficial: Desprezível. Ação Antrópica e Dinâmica de Conjunto: Neste lote não existe intervenção antrópica, porém nas suas proximidades estão realizando desmatamentos à base de moto-serra e "caixa-de-fósforo"/queimadas, que provocarão a extinção da fauna e flora.

Fonte: Passos, 10/04/2016.

ferramenta pertinente para responder às problemáticas de desenvolvimento sustentável dos territórios.

Acreditamos que a abordagem aqui explicitada, resultante de várias investigações sobre o terreno..., precedidas, regra geral, de reflexões, elaborações e reelaborações do caráter teórico, metodológico e epistemológico da aplicação da "paisagem indicadora” é coerente e totalmente válida, notadamente em territórios de difícil acesso e de mudanças muito rápidas.

A fase inicial de mise en valeur do território está sedimentada. Infelizmente com lesionamentos agudos da paisagem e, pior, sem o necessário retorno social. Atualmente, o Vale do Guaporé-Jauru é terra de pecuária, de baixo IDH, de poucas oportunidades de empregos... é, literalmente, uma região deprimida.

A economia dos municípios dessa região Sudoeste do estado do Mato Grosso, está sustentada pela pecuária extensiva, alguns projetos de silvicultura de Tecoma grandis e, notadamente dos royalties proporcionados pelas PCH - Pequenas Centrais $\mathrm{Hi}$ - droelétricas - pelas UHEs - Usinas Hidroelétricas instaladas no rio Jauru.

\section{Bibliografia}

Béringuier, P.; Dérioz, P. \& Laques, A. É. (1999). Les paysages français. Paris: Armand-Colin.

Bertrand, C. \& Bertrand G. (2002). Une géographie traversiere. L'environnement à travers territoires et temporalités. Paris: Éditions Arguments.

Bertrand, C. \& Bertrand, G. (2009). Uma geografia transversal - e de travessias. O meio ambiente através dos territórios e das temporalidades. Maringá: Massoni, 360pp (Tradução: Messias Modesto dos Passos).

Deffontaines, J. P. (1998). Les sentiers d'un géoagronome. Paris: Arguments.

Laques, A-E. (2003). Le front pionnier de São Felix do Xingu (Amazonie brésilienne): quels indicateurs pour l'analyse de ses dynamiques spatiales? OBJETS et 211 indicateurs géographiques. Avignon: Université d'Avignon, Umr Espace (Actes Avignon, n.5). 
Passos, M. M. dos (1981). Contribuição ao estudo dos cerrados em função da variação de condições ambientais. Dissertação de Mestrado. Dpto. De Geografia da FLCHUSP-SP.

Passos, M. M. dos (1996). "Teledetecção Aplicada ao Estudo da Paisagem. Sudoeste do Mato Grosso" Tese de LivreDocência, Departamento de Geografia Humana e Regional - FCT-UNESP, Câmpus de Presidente Prudente, SP-BR.

Passos, M. M. dos (1998) Amazônia: Teledetecção e Colonização.São Paulo: Fundação Editora da UNESP.
Passos, M. M. dos (2003). Biogeografia e Paisagem. Presidente Prudente; $2^{\mathrm{a}}$. ed. (Edição do Autor).

Rennó F. (2009). Le Sertão Mineiro: um territoire à la recherche de ses paysages et de ses identités. Toulouse: Tese de Doutorado.

Ribeiro, O. (2002). 2 Mato Grosso. Uma mostra fotográfica da história do último governo antes da divisão. Cuiabá: Centro América. 